\title{
Polymeric Scaffolds in Tissue Engineering Application: A Review
}

\author{
Brahatheeswaran Dhandayuthapani, Yasuhiko Yoshida, \\ Toru Maekawa, and D. Sakthi Kumar
}

\author{
Bio-Nano Electronics Research Centre, Graduate School of Interdisciplinary New Science, Toyo University, Kawagoe, \\ Saitama 350-8585, Japan \\ Correspondence should be addressed to D. Sakthi Kumar, sakthi@toyo.jp
}

Received 16 May 2011; Revised 29 June 2011; Accepted 9 July 2011

Academic Editor: Shanfeng Wang

Copyright (C) 2011 Brahatheeswaran Dhandayuthapani et al. This is an open access article distributed under the Creative Commons Attribution License, which permits unrestricted use, distribution, and reproduction in any medium, provided the original work is properly cited.

\begin{abstract}
Current strategies of regenerative medicine are focused on the restoration of pathologically altered tissue architectures by transplantation of cells in combination with supportive scaffolds and biomolecules. In recent years, considerable interest has been given to biologically active scaffolds which are based on similar analogs of the extracellular matrix that have induced synthesis of tissues and organs. To restore function or regenerate tissue, a scaffold is necessary that will act as a temporary matrix for cell proliferation and extracellular matrix deposition, with subsequent ingrowth until the tissues are totally restored or regenerated. Scaffolds have been used for tissue engineering such as bone, cartilage, ligament, skin, vascular tissues, neural tissues, and skeletal muscle and as vehicle for the controlled delivery of drugs, proteins, and DNA. Various technologies come together to construct porous scaffolds to regenerate the tissues/organs and also for controlled and targeted release of bioactive agents in tissue engineering applications. In this paper, an overview of the different types of scaffolds with their material properties is discussed. The fabrication technologies for tissue engineering scaffolds, including the basic and conventional techniques to the more recent ones, are tabulated.
\end{abstract}

\section{Introduction}

The field of tissue engineering has advanced dramatically in the last 10 years, offering the potential for regenerating almost every tissue and organ of the human body. Tissue engineering and the related discipline of regenerative medicine remain a flourishing area of research with potential new treatments for many more disease states. The advances involve researchers in a multitude of disciplines, including cell biology, biomaterials science, imaging, and characterization of surfaces and cell material interactions. Tissue engineering aims to restore, maintain, or improve tissue functions that are defective or have been lost by different pathological conditions, either by developing biological substitutes or by reconstructing tissues. The general strategies adopted by tissue engineering can be classified into three groups [1]: (i) Implantation of isolated cells or cell substitutes into the organism, (ii) delivering of tissueinducing substances (such as growth factors), and (iii) placing cells on or within different matrices. The last of these strategies is more frequently associated with the concept of tissue engineering, that is, the use of living cells seeded on a natural or synthetic extracellular substrate to create implantable pieces of the organism [2].

Scaffold design and fabrication are major areas of biomaterial research, and they are also important subjects for tissue engineering and regenerative medicine research [1]. Scaffold plays a unique role in tissue regeneration and repair. During the past two decades, many works have been done to develop potentially applicable scaffold materials for tissue engineering. Scaffolds are defined as three-dimension porous solid biomaterials designed to perform some or all of the following functions: (i) promote cell-biomaterial interactions, cell adhesion, and ECM deposition, (ii) permit sufficient transport of gases, nutrients, and regulatory factors to allow cell survival, proliferation, and differentiation, (iii) biodegrade at a controllable rate that approximates the rate of tissue regeneration under the culture conditions of interest, and (iv) provoke a minimal degree of inflammation or toxicity in vivo [3]. The developing scaffolds with the optimal 
characteristics, such as their strength, rate of degradation, porosity, and microstructure, as well as their shapes and sizes, are more readily and reproducibly controlled in polymeric scaffolds [4]. The few scaffolds that have displayed biological activity have induced regeneration of tissues and organs that do not regenerate spontaneously and have been referred as regeneration templates. Biological scaffolds are derived from human, animal tissues and synthetic scaffolds from polymers. The first biologically active scaffold was synthesized in 1974; its degradation behavior and exceptionally low antigenicity in vivo, as well as its thromboresistant behavior in vitro, were described [5]. The initial patent describing these scaffolds was granted in 1977 [6]. Principles for synthesizing a biologically active scaffold, including the critical importance of the degradation rate, was described in detail in 1980 [7]. The first reports of induced regeneration of tissue in an adult (dermis) by a scaffold in animals $[8,9]$ and humans [10], peripheral nerve regeneration across a gap of unprecedented length [11], and regeneration of the conjunctiva [12].

Biomaterials play a critical role in this technology by acting as synthetic frameworks referred as scaffolds, matrices, or constructs. The state of the art in biomaterials design has continuously evolved over the past few decades. In recent years, there has been increasing importance on materials that could be used in biomedical areas. Biomaterials intended for biomedical applications target to develop artificial materials that can be used to renovate or restore function of diseased or traumatized tissues in the human body and thus improve the quality of life. After an early empirical phase of biomaterials selection based on availability, design attempts were primarily focused on either achieving structural/mechanical performance or on rendering biomaterials inert and thus unrecognizable as foreign bodies by the immune system. Biomaterials used as implants in the form of sutures, bone plates, joint replacements, ligaments, vascular grafts, heart valves, intraocular lenses, dental implants, and medical devices like pacemakers, biosensors, and so forth $[13,14]$.

In the last four decades, significant advances have been made in the progress of scaffolds for biomedical applications. This paper is intended to illustrate the various scaffolds in the field of tissue engineering. It covers the most commonly used scaffold's fabrication technologies.

\section{Natural Polymers and Synthetic Polymers for Scaffolds}

Polymers have been widely used as biomaterials for the fabrication of medical device and tissue-engineering scaffolds $[15,16]$. In biomedical applications, the criteria for selecting the materials as biomaterials are based on their material chemistry, molecular weight, solubility, shape and structure, hydrophilicity/hydrophobicity, lubricity, surface energy, water absorption degradation, and erosion mechanism. Polymeric scaffolds are drawing a great attention due to their unique properties such as high surface-to-volume ratio, high porosity with very small pore size, biodegradation, and mechanical property. They offer distinct advantages of biocompatibility, versatility of chemistry, and the biological properties which are significant in the application of tissue engineering and organ substitution. Researchers have attempted to grow skin and cartilage [17], bone and cartilage [18], liver [19], heart valves and arteries [20], bladder [21], pancreas [22], nerves [23], corneas [24], and various other soft tissues [25].

Scaffold materials can be synthetic or biologic, degradable or nondegradable, depending on the intended use [13]. The properties of polymers depend on the composition, structure, and arrangement of their constituent macromolecules. It can be categorized into different types in terms of their structural, chemical, and biological characteristics, for example, ceramics, glasses, polymers, and so forth. Naturally occurring polymers, synthetic biodegradable, and synthetic nonbiodegradable polymers are the main types of polymers used as biomaterials.

Natural polymers can be considered as the first biodegradable biomaterials used clinically [26]. Natural materials owing to the bioactive properties have better interactions with the cells which allow them to enhance the cells' performance in biological system. Natural polymers can be classified as proteins (silk, collagen, gelatin, fibrinogen, elastin, keratin, actin, and myosin), polysaccharides (cellulose, amylose, dextran, chitin, and glycosaminoglycans), or polynucleotides (DNA, RNA) [27].

Synthetic biomaterial guidance provided by biomaterials may facilitate restoration of structure and function of damaged or diseased tissues. Synthetic polymers are highly useful in biomedical field since their properties (e.g., porosity, degradation time, and mechanical characteristics) can be tailored for specific applications. Synthetic polymers are often cheaper than biologic scaffolds; it can be produced in large uniform quantities and have a long shelf time. Many commercially available synthetic polymers show physicochemical and mechanical properties comparable to those of biological tissues. Synthetic polymers represent the largest group of biodegradable polymers, and they can be produced under controlled conditions. They exhibit, in general, predictable and reproducible mechanical and physical properties such as tensile strength, elastic modulus, and degradation rate [28]. PLA, PGA, and PLGA copolymers are among the most commonly used synthetic polymers in tissue engineering [29]. PHA belongs to a class of microbial polyesters and is being increasingly considered for applications in tissue engineering [30].

Bioactive ceramics, such as HAP, TCP, and certain compositions of silicate and phosphate glasses (bioactive glasses) and glass-ceramics (such as apatite-wollastonite) react with physiological fluids and through cellular activity form tenacious bonds to hard and in some cases soft tissue engineering [31]. However, their biocompatibility and biodegradability are often insufficient, limiting their potential use in the clinical side. We can overcome these issues by blending synthetic and natural polymers or by using composite materials that improve the scaffold properties and thereby allowing controlled degradation [32] and improving the biocompatibility in tissue engineering applications [33]. The combination of degradable polymers and inorganic bioactive particles represents the approach in terms of achievable mechanical and biological performance in hard tissue [34]. 


\section{Three-Dimensional Polymeric Scaffold Fabrication and Different Types of Scaffolds}

In an era of decreasing availability of organs for transplantation and a growing need for suitable replacements, the emerging field of tissue engineering gives hope to patients who desperately require tissue and organ substitutes. Since 1980, researchers have developed many novel techniques to shape polymers into complex architectures that exhibit the desired properties for specific tissue-engineering applications. These fabrication techniques result in reproducible scaffolds for the regeneration of specific tissues. Polymer scaffolds can provide mechanical strength, interconnected porosity and surface area, varying surface chemistry, and unique geometries to direct tissue regeneration [138]. Scaffolding is essential in this endeavor to act as a threedimensional template for tissue ingrowths by mimicking ECM [139]. These key scaffold characteristics can be tailored to the application by careful selection of the polymers, additional scaffold components, and the fabrication technique. Typical scaffold designs have included meshes, fibers, sponges and foams, and so forth. These designs are chosen because they promote uniform cell distribution, diffusion of nutrients, and the growth of organized cell communities [140]. The fabrication technique for tissue engineering scaffolds depends almost entirely on the bulk and surface properties of the material and the proposed function of the scaffold. Most techniques involve the application of heat and/or pressure to the polymer or dissolving it in an organic solvent to mold the material into its desired shape. While each method presents distinct advantages and disadvantages, the appropriate technique must be selected to meet the requirements for the specific type of tissue. Scaffolds structure development is directly related to many methods, which are listed in Table 1.

Large numbers of scaffolds from different biomaterials are available for clinical use which is listed in Table 2. In order to repair and regenerate lost or damaged tissue and organs, 3D scaffolds must be designed, fabricated, and utilized to regenerate the tissue similar in both anatomical structure and function to the original tissue or organ to be replaced or repaired. Different types of scaffolds, including porous scaffold, microsphere scaffold, hydrogel scaffold, fibrous scaffold, polymer-bioceramic composite scaffold, and acellular scaffolds are described in this paper.

\section{Porous Scaffold}

The three-dimensional polymeric porous scaffolds with higher porosities having homogeneous interconnected pore network are highly useful for tissue engineering. Sponge or foam porous scaffold have been used in tissue engineering applications [50], especially for growth of host tissue, bone regrowth, or organ vascularization. Their porous network simulates the ECM architecture allowing cells to interact effectively with their environment. Though foams and sponges are more mechanically stable compared to mesh structures, their use is still limited due to the open spaces present throughout the scaffold. A foam polymeric scaffold approach has several potential advantages for proliferating or adherent cell lines such as (a) provide a physical surface onto which the cells can lay their own ECM, (b) may inhibit cell growth of adherent contact-inhibited cells, (c) provides improved nutrient transport to the center of the device through the porous interconnecting channel network, and (d) may limit cluster size to the pore size of the foam and thereby eliminating very large clusters that can potentially develop a necrotic center. Depending on the choice of solvent and phase separating conditions, the foams can be controlled to form either random or oriented pore architectures [141].

Improvement in the structure and increased pore interconnectivity of the porous scaffold is required for the development of artificial blood vessels or peripheral nerve growth. Precise three-dimensional shapes are required which lead to the development of sophisticated extrusion technologies [142] and methods of adhering porous membranes to the desirable shapes [143]. Ideal pore sizes vary for different cells and tissues [144]. Porous scaffolds can be manufactured with specific pore size, porosity, surface-area-to-volume ratio and crystallinity. Porous controlled-release systems contain pores that are large enough to enable diffusion of the drug [145]. Synthetic biodegradable polymers such as PLLA, PGA, PLGA [50], PCL [146], PDLLA, PEE based on PEO, and PBT [147] are used as porous scaffolding materials. For enhanced control over porosity and pore diameter as compared to most fabrication methods, a solvent casting and particulate leaching technique was developed. A modern method for creating porous scaffolds composed of nano- and microscale biodegradable fibers by electrospinning is a latest development in this field.

\section{Hydrogel Scaffold}

In the last decade, hydrogels have played an ever increasing role in the revolutionary field of tissue engineering where they are used as scaffolds to guide the growth of new tissues. The design and application of biodegradable hydrogels has dramatically increased the potential impact of hydrogel materials in the biomedical field and enabled the development of exciting advances in controlled drug delivery and tissue engineering applications [148]. Hydrogels comprised of naturally derived macromolecules have potential advantages of biocompatibility, cell-controlled degradability, and intrinsic cellular interaction. They may exhibit batch variations and generally exhibit a narrow and limited range of mechanical properties. In contrast, synthetic polymers can be prepared with precisely controlled structures and functions. Hydrogels have structural similarity to the macromolecular-based components in the body and are considered biocompatible [149]. Gels are formed when the network is covalently crosslinked [150]. Hydrogels are made either from synthetic or natural polymers, which are crosslinked through either covalent or noncovalent bonds. Hydrogels in tissue engineering must meet a number of design criteria to function appropriately and promote new tissue formation. These criteria include both classical physical parameters (e.g., degradation and mechanics) as well as 
TABLE 1: Scaffolds' fabrication techniques in tissue engineering applications.

\begin{tabular}{|c|c|c|c|}
\hline Method & Polymers & Unique factors & Application \\
\hline \multicolumn{4}{|c|}{ Biodegradable porous scaffold fabrication } \\
\hline $\begin{array}{l}\text { Solvent casting/salt leaching } \\
\text { method [35-37] }\end{array}$ & $\begin{array}{l}\text { Absorbable polymer (PLLA, } \\
\text { PLGA, collagen, etc.) }\end{array}$ & $\begin{array}{l}\text { Biodegradable controlled } \\
\text { porous scaffolds }\end{array}$ & $\begin{array}{l}\text { Bone and cartilage tissue } \\
\text { engineering }\end{array}$ \\
\hline $\begin{array}{l}\text { Ice particle leaching method } \\
{[38-40]}\end{array}$ & PLLA \& PLGA & $\begin{array}{l}\text { Control of pore structure and } \\
\text { production of thicker scaffolds }\end{array}$ & $\begin{array}{l}\text { Porous 3D scaffolds for bone } \\
\text { tissue engineering }\end{array}$ \\
\hline $\begin{array}{l}\text { Gas foaming/salt leaching } \\
\text { method }[41-43]\end{array}$ & PLLA, PLGA \& PDLLA & $\begin{array}{l}\text { Controlled porosity and pore } \\
\text { structure sponge }\end{array}$ & $\begin{array}{l}\text { Drug delivery and tissue } \\
\text { engineering }\end{array}$ \\
\hline \multicolumn{4}{|l|}{ Microsphere fabrication } \\
\hline $\begin{array}{l}\text { Solvent evaporation technique } \\
{[44-46]}\end{array}$ & PLGA, PLAGA & $\begin{array}{l}\text { High-density cell culture, due } \\
\text { to the extended surface area }\end{array}$ & Bone repair \\
\hline $\begin{array}{l}\text { Particle aggregated scaffold } \\
\text { [47-49] }\end{array}$ & Chitosan, HAP & High mechanical stability & $\begin{array}{l}\text { Bone, cartilage, or } \\
\text { osteochondral tissue } \\
\text { engineering }\end{array}$ \\
\hline Freeze drying method [50-52] & $\begin{array}{l}\text { PLGA, PLLA, PGA, PLGA/PPF, } \\
\text { Collagen, and Chitosan }\end{array}$ & $\begin{array}{l}\text { 3D porous sponge structure, } \\
\text { durable and flexible }\end{array}$ & Tissue engineering scaffolds \\
\hline $\begin{array}{l}\text { Thermally induced phase } \\
\text { separation }[53,54]\end{array}$ & PEG, PLLA & $\begin{array}{l}\text { Highly porous scaffold for } \\
\text { cellular transplantation }\end{array}$ & $\begin{array}{l}\text { Complicated shapes for tissue } \\
\text { engineering applications }\end{array}$ \\
\hline \multicolumn{4}{|l|}{ Injectable gel scaffold fabrication } \\
\hline $\begin{array}{l}\text { Ceramic-based injectable } \\
\text { scaffolds [55-57] }\end{array}$ & $\begin{array}{l}\text { CP ceramics, HAp, TCP, BCP, } \\
\text { and BG }\end{array}$ & Porosity and bioresorbability & Cartilage tissue engineering \\
\hline $\begin{array}{l}\text { Hydrogel-basedinjectable } \\
\text { scaffolds [58-60] }\end{array}$ & $\begin{array}{l}\text { Hydrophilic/hydrophobic } \\
\text { diblock and triblock copolymer } \\
\text { combinations of PLA, PGA, } \\
\text { PLGA, and PEG. Copolymers of } \\
\text { PEO and PPO and polyoxamer. } \\
\text { alginates, collagen, chitosan, } \\
\text { HA, and fibroin }\end{array}$ & $\begin{array}{l}\text { Biomimetically, exhibit } \\
\text { biocompatibility and cause } \\
\text { minimal inflammatory } \\
\text { responses, thrombosis, and } \\
\text { tissue damage }\end{array}$ & $\begin{array}{l}\text { Cartilage, bone tissue } \\
\text { engineering, and drug delivery }\end{array}$ \\
\hline \multicolumn{4}{|l|}{ Hydrogel scaffold fabrication } \\
\hline Micromolding [61-63] & Alginate, PMMA, HA, PEG & $\begin{array}{l}\text { Microgels, biologically } \\
\text { degradable, mechanical and } \\
\text { physical Complexity }\end{array}$ & $\begin{array}{l}\text { Insulin delivery, gene therapy, } \\
\text { bioreactor, and } \\
\text { immunoisolation }\end{array}$ \\
\hline Photolithography [64-66] & $\begin{array}{l}\text { Chitosan, fibronectin, HA, } \\
\text { PEG, PNIAAm, PAA, PMMA, } \\
\text { PAam, and PDMAEM }\end{array}$ & $\begin{array}{l}\text { Microwells, microarrays, } \\
\text { controlled size and shape }\end{array}$ & $\begin{array}{l}\text { Microdevices, biosensors, } \\
\text { growth factors, matrix } \\
\text { components, forces, and } \\
\text { cell-cell interactions }\end{array}$ \\
\hline Microfluidics [67-69] & $\begin{array}{l}\text { PGS, PEG, calcium alginate, } \\
\text { silicon and PDMS }\end{array}$ & $\begin{array}{l}\text { Microbeads, microrods, valves, } \\
\text { and pumps }\end{array}$ & $\begin{array}{l}\text { Sensing, cell separation, } \\
\text { cell-based microreactors, and } \\
\text { controlled microreactors, }\end{array}$ \\
\hline Emulsification [70-72] & Gelatin, HA, and collagen & $\begin{array}{l}\text { Microgels, microsensors, } \\
\text { cell-based diagnostics }\end{array}$ & $\begin{array}{l}\text { Sustainable and controllable } \\
\text { drug delivery therapies }\end{array}$ \\
\hline \multicolumn{4}{|l|}{ Acellular scaffold fabrication } \\
\hline $\begin{array}{l}\text { Decellularisation process } \\
\text { [73-75] }\end{array}$ & Biological tissues & $\begin{array}{l}\text { Retain anatomical structure, } \\
\text { native ECM, and similar } \\
\text { biomechanical properties }\end{array}$ & Tissue engineering \\
\hline \multicolumn{4}{|l|}{ Keratin scaffold fabrication } \\
\hline Self-assembled process [76-78] & Keratin & Biocompatibility & $\begin{array}{l}\text { Drug delivery, wound healing, } \\
\text { soft tissue augmentation, } \\
\text { synthetic skin, coatings for } \\
\text { implants, and scaffolds for } \\
\text { tissue engineering }\end{array}$ \\
\hline
\end{tabular}


Table 1: Continued.

\begin{tabular}{|c|c|c|c|}
\hline Method & Polymers & Unique factors & Application \\
\hline \multicolumn{4}{|l|}{ Fibrous scaffold fabrication } \\
\hline $\begin{array}{l}\text { Nanofiber electrospinning } \\
\text { process [79-81] }\end{array}$ & $\begin{array}{l}\text { PGA, PLA, PLGA, PCL } \\
\text { copolymers, collagen, elastin, } \\
\text { and so forth }\end{array}$ & $\begin{array}{l}\text { High surface area, } \\
\text { biomechanical, and } \\
\text { biocompatibility }\end{array}$ & $\begin{array}{l}\text { Drug delivery, wound healing, } \\
\text { soft tissue synthetic skin, and } \\
\text { scaffolds for tissue engineering }\end{array}$ \\
\hline $\begin{array}{l}\text { Microfiber wet-spinning } \\
\text { process }[82-84]\end{array}$ & PLGA, PLA, chitosan, and PCL & $\begin{array}{l}\text { Biocompatible fibres with good } \\
\text { mechanical properties }\end{array}$ & $\begin{array}{l}\text { Solar sails, reinforcement, } \\
\text { vascular grafts, nonwetting } \\
\text { textile surfaces, and scaffolds } \\
\text { for tissue }\end{array}$ \\
\hline $\begin{array}{l}\text { Nonwoven fibre by melt-blown } \\
\text { process [ } 85-87]\end{array}$ & Polyesters, PGA, and PDO & $\begin{array}{l}\text { Submicron fiber size, highly } \\
\text { porous scaffold }\end{array}$ & $\begin{array}{l}\text { Filtration, membrane } \\
\text { separation, protective military } \\
\text { clothing, biosensors, wound } \\
\text { dressings, and scaffolds for } \\
\text { tissue engineering }\end{array}$ \\
\hline \multicolumn{4}{|l|}{ Functional scaffold fabrication } \\
\hline $\begin{array}{l}\text { Growth factor's release process } \\
{[88-90]}\end{array}$ & $\begin{array}{l}\text { Collagen, gelatin, alginate, } \\
\text { chitosan, fibrin, PLGA, PLA, } \\
\text { and PEG }\end{array}$ & $\begin{array}{l}\text { Membranes, hydrogels, foams, } \\
\text { microsphere, and particles }\end{array}$ & $\begin{array}{l}\text { Angiogenesis, bone } \\
\text { regeneration, and wound } \\
\text { healing }\end{array}$ \\
\hline \multicolumn{4}{|l|}{ Ceramic scaffold fabrication } \\
\hline $\begin{array}{l}\text { Sponge replication method } \\
{[91-93]}\end{array}$ & $\begin{array}{l}\text { PU sponge, PVA, TCP, BCP or } \\
\text { calcium sulfate }\end{array}$ & $\begin{array}{l}\text { Interconnected porous ceramic } \\
\text { scaffolds }\end{array}$ & Bone tissue engineering \\
\hline
\end{tabular}

Coating on: metals, glasses, inorganic ceramics and organic polymers (PLGA, PS, PP, silicone, and PTFE), collagens, fibres of silk, and hairs
Simple calcium phosphate coating method [94-96]
Improve biocompatibility or enhance the bioreactivity
Orthopedic application

Automation and direct organ fabrication

Inkjet printing process [97-100] Sodium alginate

Melt-based rapid prototyping process [101, 102]

Computer-aided design (CAD) data manipulation techniques [103-105]

Organ printing $[106,107]$

Tubular collagen gel blends
Biodegradeable polymers or

Scaffold sterilization

Ethylene oxide gas (EOG)

[108-110]

Gamma-radiation sterilization [111-113]

Electron beam radiation [114-116]

Dry-heat sterilization $[117,118]$
To build complex tissues composed of multiple cell types (Hydrogel scaffold)

Complex 3D solid object, good mechanical strength

Design and fabrication of patient-specific scaffolds and automated scaffold assembly algorithm

Layer by layer deposition of cells or matrix

Biosensor development, microdeposition of active proteins on cellulose, biochips and acellular polymeric scaffolds

Honey comb structure scaffold, hard-tissue scaffolds

Develop a program algorithm that can be used to design scaffold internal architectures

To print complex 3D organs with computer-controlled,

For degradable polymers and porous scaffolds, high penetration ability, and compatibility

Proven process is safe, reliable, and highly effective at treating single-use medical devices

Compatibility, low penetration, in line sterilization of thin products

Efficacy, speed, process simplicity, and lack of toxic residues

Removal of all contamination, and scaffold can be reused
Absolute freedom from biological contamination in scaffolds

Surgical disposables: surgical sutures, bandages, dressings, gauge pads, implants Commercially successful technology for sterilizing a variety of disposable medical devices with a wide range of densities

Heat is absorbed by the exterior surface of scaffold and then passed inward to the next layer Porous scaffold for living cell immobilization 
TABLE 2: List of commercial polymeric scaffolds' products.

\begin{tabular}{|c|c|c|c|}
\hline Polymer & Property & Biomedical application & Trade name \\
\hline \multirow[t]{2}{*}{ PGA } & Regenerate biological tissue [121] & $\begin{array}{l}\text { First biodegradable synthetic suture } \\
\text { in } 1969\end{array}$ & DEXON \\
\hline & Good mechanical properties [122] & Bone internal fixation devices & Biofix \\
\hline \multirow[t]{5}{*}{ PLLA } & Good tensile strength & Orthopaedic fixation devices & $\begin{array}{l}\text { Bio-Anchor, Meniscal Stinger, } \\
\text { The Clearfix Meniscal Dart }\end{array}$ \\
\hline & Improved suture [123] & $\begin{array}{l}\text { High-strength fibers (FDA approved } \\
\text { at 1971) }\end{array}$ & DEXON \\
\hline & Nondegradable fibers [124] & $\begin{array}{l}\text { Ligament replacement or } \\
\text { augmentation devices }\end{array}$ & Dacron \\
\hline & Fiber-based devices [125] & Blood vessel conduits & \\
\hline & Injectable form & $\begin{array}{l}\text { People with human } \\
\text { immunodeficiency virus or } \\
\text { correction of facial fat loss }\end{array}$ & \\
\hline PLDLA & Better property modulation [126] & Bioresorbable implant material & Resomer \\
\hline \multirow[t]{2}{*}{ PLGA } & High degradation & Multifilament suture & Vicryl, Vicryl Rapid \& CRYL \\
\hline & Form of meshes & Skin graft & Vicryl Mesh \\
\hline PLGA-collagen & Matrix & Tissue regeneration membrane & CYTOPLAST Resorb \\
\hline \multirow[t]{2}{*}{ PLGA } & Prostate cancer & Drug delivery vehicle & LUPRON DEPOT \\
\hline & & $\begin{array}{l}\text { First commercially developed } \\
\text { monofilament suture (1980) }\end{array}$ & PDS \\
\hline PDS & $\begin{array}{l}\text { Fixation screws for small bone and } \\
\text { osteochondral fragments }\end{array}$ & Orthopaedic applications & Pins \\
\hline PCL & Long-term zero-order release [26] & Long-term contraceptive device & Capronor \\
\hline PDLLA-CL & Fibers less stiff & Monofilament suture & MONACRYL \\
\hline $\begin{array}{l}\text { PGCL, PLCL, and } \\
\text { PEG }\end{array}$ & Bioresorbable multiblock & $\begin{array}{l}\text { Drug delivery vehicle for small, and } \\
\text { medium-sized biologically active } \\
\text { molecules }\end{array}$ & SynBiosys \\
\hline PCLTMC & multiblock & Flexible suture materials & Maxon \\
\hline and PGCL & & Orthopaedic tacks and screws & Acufex \\
\hline PHBHV & Piezoelectricity property [127] & $\begin{array}{l}\text { Bone pins and plates and drug } \\
\text { delivery }\end{array}$ & \\
\hline PEU & $\begin{array}{l}\text { High porous \& no adverse effect } \\
{[128]}\end{array}$ & Tissue engineering application & Degrapol \\
\hline LDI-based PU & $\begin{array}{l}\text { Injectable \& good mechanical } \\
\text { property [129] }\end{array}$ & $\begin{array}{l}\text { Orthopaedic applications \& bone } \\
\text { cement }\end{array}$ & Polynova \\
\hline PEAs & $\begin{array}{l}\text { Potential bioresorbable suture } \\
\text { materials }\end{array}$ & $\begin{array}{l}\text { Site-specific delivery of small } \\
\text { hydrophobic drugs and peptides }\end{array}$ & CAMEO \\
\hline POE & Hydrophobic, surface eroding [130] & $\begin{array}{l}\text { Drug delivery applications and } \\
\text { ocular applications }\end{array}$ & Alzamer \\
\hline Polyanhydrides & $\begin{array}{l}\text { Surface erosion \& biocompatibility } \\
\text { Evaluations [131] }\end{array}$ & $\begin{array}{l}\text { Chemotherapeutic, brain cancer } \\
\text { (FDA approved) }\end{array}$ & Gliadel \\
\hline \multirow[t]{4}{*}{ PCA } & $\begin{array}{l}\text { Absorb or encapsulate a wide range } \\
\text { of drug or protein molecules [132] }\end{array}$ & $\begin{array}{l}\text { First biodegradable polymers used } \\
\text { for developing nanoparticles for drug } \\
\text { delivery application }\end{array}$ & \\
\hline & $\begin{array}{l}\text { Synthetic surgical glue, skin adhesive, } \\
\text { and an embolic material }\end{array}$ & $\begin{array}{l}\text { Tissue adhesives for topical skin } \\
\text { application (FDA approved) }\end{array}$ & Dermabond \\
\hline & $\begin{array}{l}\text { Major component of skin and other } \\
\text { musculoskeletal tissues [133] }\end{array}$ & $\begin{array}{l}\text { Bilayer skin substitute (FDA } \\
\text { approved) }\end{array}$ & $\begin{array}{l}\text { Integra Dermal Regeneration } \\
\text { Template }\end{array}$ \\
\hline & & Wound dressings & Biobrane \&Alloderm \\
\hline Collagen & $\begin{array}{l}\text { Scaffolds for cardiovascular, } \\
\text { musculoskeletal \& nervous tissue } \\
\text { engineering [133] }\end{array}$ & Bioengineered skin equivalents & TransCyte \\
\hline
\end{tabular}


Table 2: Continued.

\begin{tabular}{llll}
\hline Polymer & Property & Biomedical application & Trade name \\
\hline HA & $\begin{array}{l}\text { Promote angiogenesis [134] } \\
\text { Sponge as a carrier vehicle for } \\
\text { osteoinductive protein [135] }\end{array}$ & $\begin{array}{l}\text { Wound dressing application } \\
\text { Synthetic bone graft }\end{array}$ & HYAFF \\
\hline HMW viscous HA & Injectable soft tissue fillers [136] & $\begin{array}{l}\text { Corneal transplantation and } \\
\text { glaucoma surgery }\end{array}$ & AMVISC \& AMVISC Plus \\
\hline Viscous HA & Synovial fluid substitute [137] & $\begin{array}{l}\text { To relieve pain and improve join } \\
\text { mobility in osteoarthritis patients }\end{array}$ & SYNVISC,ORTHOVISC \\
\hline
\end{tabular}

biological performance parameters (e.g., cell adhesion). It is commonly believed that the degradation rates of tissue scaffolds must be matched to the rate of various cellular processes in order to optimize tissue regeneration $[151,152]$. Therefore, the degradation behavior of all biodegradable hydrogels should be well defined, reproducible, and tunable via hydrogel chemistry or structure. Biocompatible hydrogels are currently used in cartilage wound healing, bone regeneration, wound dress, and as carriers for drug delivery [153]. Hydrogel with growth factor can act directly to support the development and differentiation of cells in the newly formed tissues [154]. Hydrogels are often favorable for promoting cell migration, angiogenesis, high water content, and rapid nutrient diffusion [155]. The hydrogel scaffolds have received intensive study for their use in the engineering of replacement connective tissues, primarily due to their biochemical similarity with the highly hydrated GAG components of connective tissues. Examples of hydrogelforming polymers of natural origin are collagen [156], gelatin [157], fibrin [158], HA [159], alginate [160], and chitosan [161]. The synthetic polymers are PLA [162], PPFderived Copolymers [163], PEG-derivatives, and PVA [164].

\section{Fibrous Scaffold}

The development of nanofibers has enhanced the scope for fabricating scaffolds that can potentially mimic the architecture of natural human tissue at the nanometer scale. Currently, there are three techniques available for the synthesis of nanofibers: electrospinning, self-assembly, and phase separation. Of these, electrospinning is the most widely studied technique and also seems to exhibit the most promising results for tissue engineering applications. Nanofibers synthesized by self-assembly [165] and phase separation [50] have had relatively limited studies that explored their application as scaffolds for tissue engineering. The high surface-area-to-volume ratio of the nanofibers combined with their microporous structure favors cell adhesion, proliferation, migration, and differentiation, all of which are highly desired properties for tissue engineering applications $[166,167]$. Nanofibers used as scaffolds for musculoskeletal tissue engineering including bone, cartilage, ligament, and skeletal muscle, skin, vascular, neural tissue engineering, and as vehicle for the controlled delivery of drugs, proteins, and DNA [168]. Natural polymers and synthetic polymers explored for the fabrication of nanofibers such as collagen
[169], gelatin [170], chitosan [171], HA [172], silk fibroin [173], PLA [174], PU [175], PCL [176], PLGA [177], PEVA [178], and PLLA-CL [179] are fibrous scaffold in biomedical application. The blending (or mixing) technique is a common choice for the nanofiber functionalization. However, most of the polymer nanofibers do not possess any specific functional groups, and they must be specifically functionalized for successful applications. The most popular and simplest nanofiber modification methods are physical blending and coating. Surface grafting polymerization has also been used for attaching ligand molecules and adhesive proteins on nanofiber surface for application of affinity membrane and tissue engineering scaffold, respectively. Drugs, growth factors, and genes can be directly mixed into the polymer solution and electrospun to prepare drug carriers with controlled release properties [180].

\section{Microsphere Scaffold}

Microsphere-based tissue engineering scaffold designs have attracted significant attention in recent years [181]. Laurencin et al. [44] initially used a microsphere-based approach for tissue engineering scaffold. Microsphere scaffolds are having spatial extension and temporal duration control which provides the stiffness gradients for interfacial tissue engineering [182]. Microsphere scaffolds are increasingly used as drug delivery systems and in advanced tissue engineering applications such as gene therapy, antibiotic treatment of infected bone, and so forth [183]. The influence of nanotechnology on scaffold design and the possibility of sustained release formulations of growth factors via microspheres are showing promising developments. Microsphere scaffolds are generally a polymer matrix used for drug encapsulation for the release of drugs at a relatively slow rate over a prolonged period of time [184]. Polymers with low molecular weight used in developing porous microspheres for the rapid release of the drug, while polymers with high molecular weight for developing microspheres for a slower drug release profile which can be achieved due to its dense nature [185]. Injectable microspheres have also been developed for the controlled delivery of drugs [186]. Microspheres as building blocks offer several benefits, including ease of fabrication, control over morphology, physicochemical characteristics, and its versatility of controlling the release kinetics of encapsulated factors [187]. The methods used to produce microsphere-based scaffolds have utilized heat 
sintering [188, 189], solvent vapor treatment [190, 191], solvent/nonsolvent sintering method [192, 193] or nonsolvent sintering technique [181]. Particle aggregation methodology is proposed to fabricate bilayered scaffolds for osteochondral tissue engineering in order to achieve an improved integrative bone and cartilage interface which has been needed for this application. PLAGA microsphere scaffolds are in the range of trabecular bone, demonstrating the potential of the porous microsphere matrix to be used as a scaffold for loadbearing bone tissue engineering [47]. The sintered microsphere matrix shows promise as a bone regeneration scaffold. An advantage of the sintered microsphere structure is its pore interconnectivity and desirable three-dimension pore size. The gel microsphere matrix and the sintered microsphere matrix were designed using the random packing of PLAGA microspheres to create a three-dimensional porous structure for bone regeneration [194]. Composite microspheres are also used for the fabrication of polymer-ceramic matrices for bone applications [195]. Chitosan microsphere scaffolds have been produced for cartilage and osteochondral tissue engineering [48].

\section{Polymer-Bioceramic Composite Scaffold}

Development of composite materials for tissue engineering is attractive since their properties can be engineered to suit the mechanical and physiological demands of the host tissue by controlling the volume fraction, morphology, and arrangement of the reinforcing phase [196]. Ceramics used in fabricating implants can be classified as nonabsorbable (relatively inert), bioactive or surface reactive (semi-inert) [197], and biodegradable or resorbable (noninert) [198]. Alumina, zirconia, silicone nitrides, and carbons are inert bioceramics. Certain glass ceramics and dense HAP are semiinert (bioreactive), and examples of resorbable ceramics are aluminum calcium phosphate, coralline, plaster of Paris, HAP, and TCP [199]. Ceramics are known for their good compatibility, corrosion resistance, and high compression resistance. Drawbacks of ceramics include brittleness, low fracture strength, difficulty to fabricate, low mechanical reliability, lack of resilience, and high density. In recent years, humans have realized that ceramics and their composites can also be used to augment or replace various parts of body, particularly bone. Thus, the ceramics used for the latter purposes are classified as bioceramics. Polymers by themselves are generally flexible and exhibit a lack of mechanical strength and stiffness, whereas inorganic materials such as ceramics and glasses are known to be too stiff and brittle. The combination of polymers and inorganic phases leads to composite materials with improved mechanical properties due to the inherent higher stiffness and strength of the inorganic material. Secondly, addition of bioactive phases to bioresorbable polymers can alter the polymer degradation behavior of the scaffolds [200, 201]. Complications in the development of polymer bioceramics composite scaffold are (i) maintenance of strength and the stability of the interface during the degradation period and replacement by the natural host tissue and (ii) matching resorption rates to the repair rates of body tissues developed for hard tissue implants and tissue engineering scaffolds, due to their excellent biocompatibility, bioactivity, and bioresorption in calcified tissue. Highly porous polymer/ceramic composite scaffolding appears to be a promising substrate for bone tissue engineering due to its excellent mechanical properties and osteoconductivity [40]. PLGA/HAP composite scaffold has excellent biocompatibility with hard tissues and high osteoconductivity and bioactivity [50]. The composite scaffolds supported uniform cell seeding, cell ingrowth, and tissue formation. The major inorganic component of natural bone; bioceramics, including CP, HAP, and TCP are composite with PLLA [46], collagen [202], gelatin [203], chitosan [204] are widely used as scaffolding materials for bone repair.

\section{Acellular Scaffold}

Acellular tissue matrices can be prepared by manufacturing artificial scaffolds or by removing cellular components from tissues by mechanical and chemical manipulation to produce collagen-rich matrices [205-207]. These matrices slowly degrade on implantation and are generally replaced by the ECM proteins secreted by the ingrowing cells. The ultimate goal of any decellularization protocol is to remove all cellular material without adversely affecting the composition, mechanical integrity, and eventual biological activity of the remaining ECM. The decellularized biological scaffold was introduced to obtain a physiological matrix scaffold that resembles that of native blood vessels [208]. Acellular tissue matrices have proven to support cell ingrowth and regeneration of genitourinary tissues, including urethra and bladder, with no evidence of immunogenic rejection [207]. Ureteral acellular matrices were utilized as a scaffold for the ingrowth of ureteral tissue in rats [209]. Acellular bladder matrix has served as a scaffold for the ingrowth of host bladder wall components in rats. Since the structures of the proteins (e.g., collagen and elastin) in acellular matrices are well conserved and normally arranged, the mechanical properties of the acellular matrices are not significantly different from those of native bladder submucosa [209]. The matrix was prepared by mechanically and chemically removing all cellular components from bladder tissue [210]. To engineer tissues successfully, the selection of scaffolds is critical. Although various synthetic biodegradable polymer scaffolds have been developed and improved by mimicking biological structures, comparing to other scaffolds, acellular scaffolds have the following advantages.

(i) Acellular scaffolds retain their correct anatomical structure even after the decellularisation process.

(ii) Acellular scaffolds retain native ECM architecture and possess the cell adhesion ligands.

(iii) The decellularisation process considerably reduces immunological responses by completely removing cellular components.

(iv) The decellularisation process facilitates similar biomechanical properties as those of native tissues that are critical for the long-term functionality of the grafts. 
Various extracellular matrices have been utilized successfully for tissue engineering in animal models and products incorporating decellularized heart valves, small intestinal submucosa (SIS), and urinary bladder have received regulatory approval for use in human patients [211]. The obvious advantage of this scaffold is that it is composed of ECM proteins typically found in the body. When derived from a vessel, the three-dimension architecture is very similar to that of the original, thus conferring appropriate mechanical and physical properties, which is essential in identifying and predicting optimal cell environments in order to develop scaffolds for preliminary analysis and implantation. Naturally derived materials and acellular tissue matrices have the potential advantage of biological recognition. Polymer coating of a tissue-derived acellular scaffold can improve the mechanical stability and enhance the hemocompatibility of the protein matrix. Tissue engineering that has been introduced is the use of biological/polymeric composite materials as starter matrices. Such hybrids can be complex structures such as heart valves, for example, fabricated from decellularized porcine aortic valves and dip coated with a biodegradable polymer [212].

\section{Physicochemical Characterization of Scaffolds}

Polymeric scaffolds have evolved to serve not merely as carriers of cells and inductive factors, but to actively instruct cells and provide step by step guidance of tissue formation. To accomplish this goal, a thorough understanding of the chemistry and physicochemical properties of the tissue to be engineered and the materials used in this process are required. Several characterizations are required for the fabrication of successful 3D scaffolds. They are

(i) external geometry (e.g., macro-, microstructure, interconnectivity),

(ii) surface properties (e.g., surface energy, chemistry, charge, surface area),

(iii) porosity and pore size,

(iv) interface adherence \& biocompatibility,

(v) degradation characterization (e.g., biodegradation),

(vi) mechanical competence (e.g., compressive and tensile strength).

Developing scaffolds that mimic the architecture of tissue at the nanoscale is one of the most important challenges in the field of tissue engineering [168]. Polymeric scaffolds show excellent potential with mechanical properties and with wide range of degradation, the qualities which are essential for a range of tissue engineering applications [213].

\section{External Geometry}

Physical characteristics are certainly the important factors to consider when scaffolds are applied for tissue reconstruction [214]. Scaffold with proper physical characters are smart materials that can mimic natural ECM. ECM plays a key role in tissue architecture by providing structural support and tensile strength. Attachment sites for cell surface receptors are related to a wide variety of processes related to cell differentiation, tissue formation, homeostasis, and regeneration $[215,216]$. The fabrication and design of macro- to nanoscale structural architectures have received much attention in medical applications. Nano- to macroscale structure geometrically or topologically mimics the native state of ECM in living tissues. Three-dimensional scaffolds are capable of regenerating tissue and organs in their normal physiological shape. Mimicking the ECM using biomaterials would be a logical approach for engineering scaffold for a variety of tissue types. As polymer materials permit a most versatile variety of surface characteristics, efficient control over processes of ECM reconstitution can be achieved by the interaction with polymeric materials. The importance of scaffold geometry in maintaining highly interconnected porous fabrics of high surface density provides an extremely high surface-to-volume ratio, favoring cell attachment and proliferation.

\section{Surface Properties}

Surface properties include both chemical and topographical characteristics, which can control and affect cellular adhesion and proliferation [214]. The scaffold surface is the initial and primary site of interaction with surrounding cells and tissue. As most cells utilized in tissue engineering are anchorage dependent, it has been reasoned that the scaffold should facilitate their attachment. Thus, scaffolds with a large and accessible surface area are favorable. For example, high internal surface-area-to-volume ratios is essential in order to accommodate the number of cells required to replace or restore tissue or organ functions. The surface properties can be selectively modified to enhance the performance of the biomaterials. For instance, by altering the surface functionality using thin film deposition, the optimal surface, chemical, and physical properties can be attained [217, 218]. Hence, surface modification of biomaterials is becoming an increasingly popular method to improve device multifunctionality, tribological, and mechanical properties. Most of the surface modifications and immobilizations of biomolecules are performed to improve the biocompatibility of the polymeric scaffold; thereby, cells can specifically recognize the scaffold. These biomolecules include adhesive proteins like collagen, fibronectin, RGD peptides, and growth factors like bFGF, EGF, insulin, and so forth. The biomolecules can either be covalently attached, electrostatically adsorbed, or self-assembled on the biomaterial surfaces to develop brand new materials [219].

\section{Porosity and Pore Size}

Scaffolds must possess a highly porous structure with an open fully interconnected geometry for providing a large surface area that will allow cell ingrowth, uniform cell distribution, and facilitate the neovascularization of the 
construct [220]. Average pore size, pore size distribution, pore volume, pore interconnectivity, pore shape, pore throat size, and pore wall roughness are important parameters to consider while designing a scaffold. It provides a porous biocompatible network into which the surrounding tissue is induced and acts as a temporary template for the new tissue's growth and reorganization [221]. Pore size is also a very important issue because if the pores employed are too small, pore occlusion by the cells will happen, which will prevent cellular penetration, extracellular matrix production, and neovascularization of the inner areas of the scaffold. The effects of pore size on tissue regeneration has been emphasized by experiments demonstrating optimum pore size of $5 \mu \mathrm{m}$ for neovascularization [222], 5-15 $\mu \mathrm{m}$ for fibroblast ingrowth [223], $20 \mu \mathrm{m}$ for the ingrowth of hepatocytes [224], 200-350 $\mu \mathrm{m}$ for osteoconduction [225], and $20-125 \mu \mathrm{m}$ for regeneration of adult mammalian skin [226]. Pore interconnectivity is also critical to ensure that all cells are within $200 \mu \mathrm{m}$ from blood supply in order to provide for mass transfer of oxygen and nutrients [224, 227].

\section{Interface Adherence and Biocompatibility}

The term biocompatibility has been defined in many and different ways. Historically, materials that caused minimal biological responses were considered biocompatible. Biocompatibility refers to the ability of a biomaterial to perform its desired function with respect to a medical therapy, without eliciting any undesirable local or systemic effects in the recipient or beneficiary of that therapy. It should generate the most appropriate beneficial cellular or tissue response in that specific situation and optimize the clinically relevant performance of that therapy [15]. Biocompatibility of a scaffold or matrix for a tissue engineering product refers to the ability to perform as a substrate that will support the appropriate cellular activity, including the facilitation of molecular and mechanical signalling systems [228]. Some important factors that determine scaffold's biocompatibility are their chemistry, structure, and their morphology, which in turn are affected by the polymer synthesis, scaffold processing, and sterilization conditions. Recently, several biodegradable polymers such as PLA, PGA, PLGA, PDO, PTMC, and so on are extensively used or tested on a wide range of medical applications due to their good biocompatibility [229]. The behavior of the adsorption and desorption of adhesion and proliferation of different types of mammalian cells on polymeric materials depends on the surface characteristics such as wettability, hydrophilicity/hydrophobicity ratio, bulk chemistry, surface charge and charge distribution, surface roughness, and rigidity. A number of surface treatments are available to optimize the biocompatibility of surfaces in contact with living tissue, to seal in undesirable residues or additives using a coating and to regulate excretion and/or absorption using a selectively permeable surface [230]. Recently, physical and chemical surface modification methods for polymeric biomaterials to influence cell adhesion and growth have been achieved by oxidized polystyrene surface [231], ammonia plasma-treated surface [232], and plasma-deposited acetone [233].

\section{Degradation Rates}

Biodegradable polymers have revolutionized the applications of biomaterial in the field of drug delivery and implants for tissue engineering applications. Scaffold degradation can occur through mechanisms that involve physical or chemical processes and/or biological processes that are mediated by biological agents, such as enzymes in tissue remodeling. The biodegradable scaffold gradually degrades by predetermined period to be replaced by newly grown tissue from the adhered cells [1]. Degradation results in scaffold dismantling and material dissolution/resorption through the scaffolds bulk and/or surface types of degradation [234]. Polymeric scaffolds that undergo bulk degradation tend to break down the internal structure of the scaffold thus reducing the molecular mass [235]. A polymeric scaffold that primarily undergoes surface degradation can be described similarly to the dissolution of soap. The rate at which the surface degrades is usually constant. Therefore, even though the size of the scaffold becomes smaller, the bulk structure is maintained. These types of degrading scaffolds provide longer mechanical stability for the tissue to regenerate. Biodegradation of polymeric biomaterials involves cleavage of hydrolytically or enzymatically sensitive bonds in the polymer leading to polymer erosion [131]. The biodegradation rate of a polymer depends mainly on the intrinsic properties of the polymer, including the chemical structure, thev presence of hydrolytically unstable bonds, the level ofv hydrophilicity/hydrophobicity, crystalline/amorphous morphology, glass transition temperatures $(\mathrm{Tg})$, the copolymer ratio, and the molecular weight [236]. The Controllable degradation and restoration rates should match the rate of tissue growth in vitro and in vivo for biodegradable or restorable materials. The nonbiodegradable polymeric scaffolds are biologically stable, and it can provide a permanent support over time and should ideally perform during the life time of the patient. For example, PMMA is mainly used as bone cements in hip and knee replacements, and highdensity PE forms the articulating surfaces of hip and knee joints [13].

\section{Mechanical Properties}

The proper mechanical properties for a biomaterial to be used in a tissue engineering application are critical to the success of the implant. The biostability of many scaffolds depends on the factors such as strength, elasticity, and absorption at the material interface and its chemical degradation. The scaffold should have proper mechanical properties and degradation rate with the bioactive surface to encourage the rapid regeneration of the tissue [26]. It is highly essential to retain the mechanical strength of the scaffolds structure after implantation for the reconstruction of hard, load bearing tissues such as bone and cartilages. To be used successfully in tissue engineering, it is critical that a biomaterial scaffold temporarily withstands and conducts the loads and stresses that the new tissue will ultimately bear. It is important, therefore, to evaluate one or more of the 
following rheological parameters:

(i) elastic modulus_-measured strain in response to a given tensile or compressive stress along the force;

(ii) flexural modulus-measured the relationship between a bending stress and the resulting strain in response to a given tensile or compressive stress perpendicular under load;

(iii) tensile strength-maximum stress that the material can withstand before it breaks;

(iv) maximum strain-ductility of a material or total strain exhibited prior to fracture.

The low strength and rigidity of the polysaccharides limit their use to soft tissue applications. Fortunately, the options for tissue engineering are expanded by the use of fibrous proteins, whose normal function is to provide mechanical integrity and stability to biological structures. Fibrous proteins are responsible for the transduction of external mechanical forces to associated cells in a manner that influences the outcome of tissue growth [169]. The mechanical properties of bulk biomaterials are altered by their processing into scaffolds of various pore sizes and pore orientations and further that these properties will rapidly diminish as a function of implantation time [237]. The mechanical rigidity of the surrounding matrix, as well as material roughness and physical confinement, determined by three-dimensional microstructure on a subcellular and supercellular scale, respectively, may significantly modulate the outcome of the balance between cell matrix forces, leading to the remodeling of cytoarchitecture, cell polarization, alteration of downstream intracellular signaling events as well as modification of the balance of cell-cell forces [238-240]. The major factor affecting the mechanical properties and structural integrity of scaffolds, however, is their porosity, for example, pore volume, size, shape, orientation, and connectivity.

\section{Conclusions}

In summary, tissue engineering is one of the most exciting interdisciplinary and multidisciplinary research areas and is growing exponentially over time. Scaffold materials and fabrication technologies play a crucial role in tissue engineering. A wide range of polymeric scaffold was used to date in the tissue engineering area. Scaffolds should meet certain design parameters to be useful in this area, regardless of whether they originate from natural resources or are synthetically created. All these techniques for scaffold fabrication are sensitive to the various processing parameters. Innovations in the material design and fabrication processes are raising the possibility of production of implants with good performance. The scaffold should be surface compatible as well as architecturally suitable with the host environment. The interest in the principles and theories of the fabrication process with polymers would be useful to develop a new design for implants and also to understand the behavior of the scaffold in the biomedical applications. Nanotechnology can provide strategies that can help to create features on a scaffold in a dimensional range that may be adequate for cells and biomolecules. There are clear indications that as the goals of biomedical engineering increase in complexity, there is need to develop novel scaffold structures.

\section{Future Directions}

Medical research continues to explore new scientific frontiers for diagnosing, treating, curing, and preventing diseases at the molecular/genetic level. Important advances have been made in the clinical use of medical implants and other devices. Presently, emphasis is placed on the design of polymeric scaffold, that is, materials that obtain specific, desired, and timely responses from surrounding cells and tissues. The need for alternative solutions to meet the demand for replacement organs and tissue parts will continue to drive advances in tissue engineering. Polymer scaffolds have all the prospective to provide a new means to control the physical and chemical environment of the biological system. There are several advantages to use biological polymers over widely utilized synthetic polymer in tissue engineering scaffold. Despite these recent improvements to the mechanical properties, porosity, and bioactivity of scaffolds, future researches are needed to overcome many remaining limitations in the fabricating process. We believe no one material will satisfy all design parameters in all applications, but a wide range of materials will find uses in various tissue engineering applications. The overall challenges in scaffold design and fabrication gives opportunity for new exciting application oriented research in scaffold design which includes polymer assembly, surface topography or chemical cues, nano-/macrostructure, biocompatibility, biodegradability, mechanical properties, directing cell function and induced formation of natural tissue.

\section{Abbreviations}

PU: Polyurethane

PS: Polysulfone

CP: Calcium phosphate

HA: Hyaluronic acid

PP: Polypropylene

BG: Bioactive glass

ECM: Extracellular matrix

PVA: Polyvinyl alcohol

PGA: Polyglycolide

PLA: Polylactide

PPF: Poly(propylene fumarate)

PCA: Polycyanoacrylate

PCL: Poly ( $\varepsilon$-caprolactone $)$

PDO: Polydioxanone

PHA: Polyhydroxyalkanoates

POE: Poly(ortho ester)

PEE: Poly(ether ester)

PEO: Poly(ethylene oxide)

PBT: Polybutylene terephthalate

HAP: Hydroxyapatite 


$\begin{array}{ll}\text { TCP: } & \text { Tricalcium phosphate } \\ \text { PEG: } & \text { Poly(ethylene glycol) } \\ \text { PEU: } & \text { Poly(ester urethane) } \\ \text { PAA: } & \text { Poly(acrylic acid) } \\ \text { LDI: } & \text { Lysine diisocyanate } \\ \text { BCP: } & \text { Biphasic calcium phosphate } \\ \text { HMW: } & \text { High molecular weight } \\ \text { PAam: } & \text { Polyacrylamide } \\ \text { PMMA: } & \text { Polymethylmethacrylate } \\ \text { PLLA: } & \text { Poly(L-lactic acid) } \\ \text { PLGA: } & \text { Poly(l-lactide-co-glycolide) } \\ \text { PTMC: } & \text { Poly(trimethylene carbonate) } \\ \text { PDMS: } & \text { Polydimethylsiloxane } \\ \text { PTFE: } & \text { Polytetrafluoroethylene } \\ \text { PEVA: } & \text { Poly(ethylene-co-vinylacetate) } \\ \text { PGCL: } & \text { Poly(glycolide-co- } \varepsilon \text {-caprolactone) } \\ \text { PLCL: } & \text { Poly(l-lactide-co-caprolactone) } \\ \text { PDLLA: } & \text { Poly(DL-lactide) } \\ \text { PLDLA: } & \text { Poly-L/D-lactide } \\ \text { PLAGA: } & \text { Poly(lactic acid-glycolic acid) } \\ \text { PHBHV: } & \text { Poly(3-hydroxybutyrate)3-hydroxyvalerate } \\ \text { PCLTMC: } & \text { Poly(caprolactone-co-trimethylene } \\ & \text { carbonate) } \\ \text { PNIPAAm: } & \text { Poly(N-isopropylacrylamide) } \\ \text { PDMAEM: } & \text { Poly(dimethylaminoethylmethacrylate) } \\ & \text { hydrochloride } \\ \text { PDLLA-CL: } & \text { Poly(D,L-lactide-co- caprolactone) } \\ \text { PLLA-CL: } & \text { Poly(l-lactide-co-e-caprolactone) } \\ \text { TCP: } & \text { Tricalcium phosphate. } \\ & \end{array}$

\section{Acknowledgment}

D. Brahatheeswaran, would like to acknowledge the Japanese Government, Ministry of Education, Culture, Sports, Science and Technology (MEXT) for the scholarships provided for the doctoral studies.

\section{References}

[1] R. Langer and J. P. Vacanti, “Tissue engineering," Science, vol. 260, no. 5110, pp. 920-926, 1993.

[2] R. M. Nerem, "Tissue engineering in the USA," Medical and Biological Engineering and Computing, vol. 30, no. 4, pp. CE8-CE12, 1992.

[3] R. Langer and D. A. Tirrell, "Designing materials for biology and medicine," Nature, vol. 428, no. 6982, pp. 487-492, 2004.

[4] J. R. Fuchs, B. A. Nasseri, and J. P. Vacanti, "Tissue engineering: a 21st century solution to surgical reconstruction," Annals of Thoracic Surgery, vol. 72, no. 2, pp. 577-591, 2001.

[5] I. V. Yannas, J. F. Burke, C. Huang, and P. L. Gordon, "Suppression of in vivo degradability and of immunogenicity of collagen by reaction with glycosaminoglycans," Polymer Preprints, vol. 16, pp. 209-214, 1975.

[6] I. V. Yannas, J. F. Burke, P. L. Gordon, and C. Huang, "Multilayer membrane useful as synthetic skin," US patent 4060081, 1977.

[7] I. V. Yannas and J. F. Burke, "Design of an artificial skin. I. Basic design principles," Journal of Biomedical Materials Research, vol. 14, no. 1, pp. 65-81, 1980.
[8] I. V. Yannas, J. F. Burke, M. Warpehoski et al., "Prompt, long-term functional replacement of skin," TransactionsAmerican Society for Artificial Internal Organs, vol. 27, pp. 1923, 1981.

[9] I. V. Yannas, J. F. Burke, D. P. Orgill, and E. M. Skrabut, "Regeneration of skin following closure of deep wounds with a biodegradable template," Transactions of the Society For Biomaterials, vol. 5, pp. 24-29, 1982.

[10] J. F. Burke, O. V. Yannas, and W. C. Quinby Jr., "Successful use of a physiologically acceptable artificial skin in the treatment of extensive burn injury," Annals of Surgery, vol. 194, no. 4, pp. 413-427, 1981.

[11] I. V. Yannas, D. P. Orgill, J. Silver, T. V. Norregaard, N. T. Zervas, and W. C. Schoene, "Polymeric template facilitates regeneration of sciatic nerves across 15-mm gap," Transactions of the Society For Biomaterials, vol. 8, p. 146, 1985.

[12] W. C. Hsu, M. H. Spilker, I. V. Yannas, and P. A. D. Rubin, "Inhibition of conjunctival scarring and contraction by a porous collagen-glycosaminoglycan implant," Investigative Ophthalmology and Visual Science, vol. 41, no. 9, pp. 2404$2411,2000$.

[13] S. Ramakrishna, J. Mayer, E. Wintermantel, and K. W. Leong, "Biomedical applications of polymer-composite materials: a review," Composites Science and Technology, vol. 61, no. 9, pp. 1189-1224, 2001.

[14] M. Vert, "Aliphatic polyesters: great degradable polymers that cannot do everything," Biomacromolecules, vol. 6, no. 2, pp. 538-546, 2005.

[15] E. Piskin, "Biodegradable polymers as biomaterials," Journal of Biomaterials Science Polymer Edition, vol. 6, pp. 775-795, 1994.

[16] Y. Ji, K. Ghosh, X. Z. Shu et al., "Electrospun threedimensional hyaluronic acid nanofibrous scaffolds," Biomaterials, vol. 27, no. 20, pp. 3782-3792, 2006.

[17] W. H. Eaglstein and V. Falanga, "Tissue engineering and the development of Apligraf a human skin equivalent," Advances in Wound Care, vol. 11, supplement 4, pp. 1-8, 1998.

[18] B. D. Boyan, C. H. Lohmann, J. Romero, and Z. Schwartz, "Bone and cartilage tissue engineering," Clinics in Plastic Surgery, vol. 26, no. 4, pp. 629-645, 1999.

[19] J. Mayer, E. Karamuk, T. Akaike, and E. Wintermantel, "Matrices for tissue engineering-scaffold structure for a bioartificial liver support system," Journal of Controlled Release, vol. 64, no. 1-3, pp. 81-90, 2000.

[20] J. E. Mayer, T. Shin'oka, and D. Shum-Tim, "Tissue engineering of cardiovascular structures," Current Opinion in Cardiology, vol. 12, no. 6, pp. 528-532, 1997.

[21] F. Oberpenning, J. Meng, J. J. Yoo, and A. Atala, "De novo reconstitution of a functional mammalian urinary bladder by tissue engineering," Nature Biotechnology, vol. 17, no. 2, pp. 149-155, 1999.

[22] E. Tziampazis and A. Sambanis, "Tissue engineering of a bioartificial pancreas: modeling the cell environment and device function," Biotechnology Progress, vol. 11, no. 2, pp. 115-126, 1995.

[23] J. Mohammad, J. Shenaq, E. Rabinovsky, and S. Shenaq, "Modulation of peripheral nerve regeneration: a tissueengineering approach. The role of amnion tube nerve conduit across a 1-centimeter nerve gap," Plastic and Reconstructive Surgery, vol. 105, no. 2, pp. 660-666, 2000.

[24] L. Germain, F. A. Auger, E. Grandbois et al., "Reconstructed human cornea produced in vitro by tissue engineering," Pathobiology, vol. 67, no. 3, pp. 140-147, 1999. 
[25] C. A. Diedwardo, P. Petrosko, T. O. Acarturk, P. A. Dimilia, W. A. Laframboise, and P. C. Johnson, "Muscle tissue engineering," Clinics in Plastic Surgery, vol. 26, no. 4, pp. 647656, 1999.

[26] L. S. Nair and C. T. Laurencin, "Biodegradable polymers as biomaterials," Progress in Polymer Science, vol. 32, no. 8-9, pp. 762-798, 2007.

[27] I. V. Yannas, "Classes of materials used in medicine: natural materials," in Biomaterials Science-An Introduction to Materials in Medicine, B. D. Ratner, A. S. Hoffman, F. J. Schoen, and J. Lemons, Eds., pp. 127-136, Elsevier Academic Press, San Diego, Calif, USA, 2004.

[28] P. Gunatillake, R. Mayadunne, and R. Adhikari, "Recent developments in biodegradable synthetic polymers," Biotechnology Annual Review, vol. 12, pp. 301-347, 2006.

[29] P. X. Ma, "Scaffolds for tissue fabrication," Materials Today, vol. 7, no. 5, pp. 30-40, 2004.

[30] L. J. Chen and M. Wang, "Production and evaluation of biodegradable composites based on PHB-PHV copolymer," Biomaterials, vol. 23, no. 13, pp. 2631-2639, 2002.

[31] L. L. Hench, "Bioceramics," Journal of the American Ceramic Society, vol. 81, no. 7, pp. 1705-1727, 1998.

[32] M. G. Cascone, N. Barbani, C. Cristallini, P. Giusti, G. Ciardelli, and L. Lazzeri, "Bioartificial polymeric materials based on polysaccharides," Journal of Biomaterials Science, vol. 12, no. 3, pp. 267-281, 2001.

[33] G. Ciardelli, V. Chiono, G. Vozzi et al., "Blends of poly( $\varepsilon$-caprolactone) and polysaccharides in tissue engineering applications," Biomacromolecules, vol. 6, no. 4, pp. 19611976, 2005.

[34] J. A. Roether, A. R. Boccaccini, L. L. Hench, V. Maquet, S. Gautier, and R. Jérôme, "Development and in vitro characterisation of novel bioresorbable and bioactive composite materials based on polylactide foams and Bioglass ${ }^{\circledR}$ for tissue engineering applications," Biomaterials, vol. 23, no. 18, pp. 3871-3878, 2002.

[35] A. G. Mikos, G. Sarakinos, S. M. Leite, J. P. Vacanti, and R. Langer, "Laminated three-dimensional biodegradable foams for use in tissue engineering," Biomaterials, vol. 14, no. 5, pp. 323-330, 1993.

[36] A. G. Mikos, A. J. Thorsen, L. A. Czerwonka et al., "Preparation and characterization of poly(l-lactic acid) foams," Polymer, vol. 35, no. 5, pp. 1068-1077, 1994.

[37] K. Ochi, G. Chen, T. Ushida et al., "Use of isolated mature osteoblasts in abundance acts as desired-shaped bone regeneration in combination with a modified poly-DL-lacticco-glycolic acid (PLGA)-collagen sponge," Journal of Cellular Physiology, vol. 194, no. 1, pp. 45-53, 2003.

[38] C. E. Holy, M. S. Shoichet, and J. E. Davies, "Engineering three-dimensional bone tissue in vitro using biodegradable scaffolds: investigating initial cell-seeding density and culture period," Journal of Biomedical Materials Research, vol. 51, no. 3, pp. 376-382, 2000.

[39] J. M. Karp, M. S. Shoichet, and J. E. Davies, "Bone formation on two-dimensional poly(DL-lactide-co-glycolide) (PLGA) films and three-dimensional PLGA tissue engineering scaffolds in vitro," Journal of Biomedical Materials Research A, vol. 64, no. 2, pp. 388-396, 2003.

[40] H. G. Kang, S. Y. Kim, and Y. M. Lee, "Novel porous gelatin scaffolds by overrun/particle leaching process for tissue engineering applications," Journal of Biomedical Materials Research B, vol. 79, no. 2, pp. 388-397, 2006.

[41] D. J. Mooney, D. F. Baldwin, N. P. Suh, J. P. Vacanti, and R. Langer, "Novel approach to fabricate porous sponges of
poly(D,L-lactic-co-glycolic acid) without the use of organic solvents," Biomaterials, vol. 17, no. 14, pp. 1417-1422, 1996.

[42] J. J. Yoon and T. G. Park, "Degradation behaviors of biodegradable macroporous scaffolds prepared by gas foaming of effervescent salts," Journal of Biomedical Materials Research, vol. 55, no. 3, pp. 401-408, 2001.

[43] W. L. Murphy, R. G. Dennis, J. L. Kileny, and D. J. Mooney, "Salt fusion: an approach to improve pore interconnectivity within tissue engineering scaffolds," Tissue Engineering, vol. 8, no. 1, pp. 43-52, 2002.

[44] C. T. Laurencin, M. A. Attawia, H. E. Elgendy, and K. M. Herbert, "Tissue engineered bone-regeneration using degradable polymers: the formation of mineralized matrices," Bone, vol. 19, no. 1, 1996.

[45] J. E. Devin, M. A. Attawia, and C. T. Laurencin, "Threedimensional degradable porous polymer-ceramic matrices for use in bone repair," Journal of Biomaterials Science, vol. 7, no. 8, pp. 661-669, 1996.

[46] B. H. Woo, J. W. Kostanski, S. Gebrekidan, B. A. Dani, B. C. Thanoo, and P. P. DeLuca, "Preparation, characterization and in vivo evaluation of 120-day poly(D,L-lactide) leuprolide microspheres," Journal of Controlled Release, vol. 75, no. 3, pp. 307-315, 2001.

[47] M. Borden, S. F. El-Amin, M. Attawia, and C. T. Laurencin, "Structural and human cellular assessment of a novel microsphere-based tissue engineered scaffold for bone repair," Biomaterials, vol. 24, no. 4, pp. 597-609, 2003.

[48] P. B. Malafaya, A. J. Pedro, A. Peterbauer, C. Gabriel, H. Redl, and R. L. Reis, "Chitosan particles agglomerated scaffolds for cartilage and osteochondral tissue engineering approaches with adipose tissue derived stem cells," Journal of Materials Science: Materials in Medicine, vol. 16, no. 12, pp. 1077-1085, 2005.

[49] P. B. Malafaya, T. C. Santos, M. van Griensven, and R. L. Reis, "Morphology, mechanical characterization and in vivo neo-vascularization of chitosan particle aggregated scaffolds architectures," Biomaterials, vol. 29, no. 29, pp. 3914-3926, 2008.

[50] R. Zhang and P. X. Ma, "Porous poly(L-lactic acid)/apatite composites created by biomimetic process," Journal of Biomedical Materials Research, vol. 45, no. 4, pp. 285-293, 1999.

[51] Y. Ohya, H. Matsunami, E. Yamabe, and T. Ouchi, "Cell attachment and growth on films prepared from poly(depsipeptide-co-lactide) having various functional groups," Journal of Biomedical Materials Research A, vol. 65, no. 1, pp. 79-88, 2003.

[52] Y. Ohya, H. Matsunami, and T. Ouchi, "Cell growth on the porous sponges prepared from poly(depsipeptide-co-lactide) having various functional groups," Journal of Biomaterials Science, vol. 15, no. 1, pp. 111-123, 2004.

[53] M. Borden, M. Attawia, Y. Khan, and C. T. Laurencin, "Tissue engineered microsphere-based matrices for bone repair: design and evaluation," Biomaterials, vol. 23, no. 2, pp. 551-559, 2002.

[54] J. Guan, K. L. Fujimoto, M. S. Sacks, and W. R. Wagner, "Preparation and characterization of highly porous, biodegradable polyurethane scaffolds for soft tissue applications," Biomaterials, vol. 26, no. 18, pp. 3961-3971, 2005.

[55] T. J. Blokhuis, M. F. Termaat, F. C. Den Boer, P. Patka, F. C. Bakker, and H. J. T. M. Haarman, "Properties of calcium phosphate ceramics in relation to their in vivo behavior," Journal of Trauma-Injury, Infection and Critical Care, vol. 48, no. 1, pp. 179-186, 2000. 
[56] T. A. Holland, J. K. V. Tessmar, Y. Tabata, and A. G. Mikos, "Transforming growth factor- $\beta 1$ release from oligo(poly(ethylene glycol) fumarate) hydrogels in conditions that model the cartilage wound healing environment," Journal of Controlled Release, vol. 94, no. 1, pp. 101-114, 2004.

[57] O. Gauthier, R. Müller, D. Von Stechow et al., "In vivo bone regeneration with injectable calcium phosphate biomaterial: a three-dimensional micro-computed tomographic, biomechanical and SEM study," Biomaterials, vol. 26, no. 27, pp. 5444-5453, 2005.

[58] B. Jeong, Y. H. Bae, and S. W. Kim, "Thermoreversible gelation of PEG-PLGA-PEG triblock copolymer aqueous solutions," Macromolecules, vol. 32, no. 21, pp. 7064-7069, 1999.

[59] S. Ibusuki, Y. Fujii, Y. Iwamoto, and T. Matsuda, "Tissueengineered cartilage using an injectable and in situ gelable thermoresponsive gelatin: fabrication and in vitro performance," Tissue Engineering, vol. 9, no. 2, pp. 371-384, 2003.

[60] J. Y. Seong, Y. J. Jun, B. Jeong, and Y. S. Sohn, "New thermogelling poly(organophosphazenes) with methoxypoly(ethylene glycol) and oligopeptide as side groups," Polymer, vol. 46, no. 14, pp. 5075-5081, 2005.

[61] J. Yeh, Y. Ling, J. M. Karp et al., "Micromolding of shapecontrolled, harvestable cell-laden hydrogels," Biomaterials, vol. 27, no. 31, pp. 5391-5398, 2006.

[62] J. Fukuda, A. Khademhosseini, Y. Yeo et al., "Micromolding of photocrosslinkable chitosan hydrogel for spheroid microarray and co-cultures," Biomaterials, vol. 27, no. 30, pp. 5259-5267, 2006.

[63] A. Khademhosseini, G. Eng, J. Yeh et al., "Micromolding of photocrosslinkable hyaluronic acid for cell encapsulation and entrapment," Journal of Biomedical Materials Research A, vol. 79, no. 3, pp. 522-532, 2006.

[64] D. J. Beebe, J. S. Moore, J. M. Bauer et al., "Functional hydrogel structures for autonomous flow control inside microfluidic channels," Nature, vol. 404, no. 6778, pp. 588590, 2000.

[65] V. A. Liu and S. N. Bhatia, "Three-dimensional photopatterning of hydrogels containing living cells," Biomedical Microdevices, vol. 4, no. 4, pp. 257-266, 2002.

[66] D. Dendukuri, D. C. Pregibon, J. Collins, T. A. Hatton, and P. S. Doyle, "Continuous-flow lithography for high-throughput microparticle synthesis," Nature Materials, vol. 5, no. 5, pp. 365-369, 2006.

[67] T. Nisisako, T. Torii, and T. Higuchi, "Droplet formation in a microchannel network," Lab on a Chip-Miniaturisation for Chemistry and Biology, vol. 2, no. 1, pp. 24-26, 2002.

[68] J. A. Burdick, A. Khademhosseini, and R. Langer, "Fabrication of gradient hydrogels using a microfluidics/photopolymerization process," Langmuir, vol. 20, no. 13, pp. 51535156, 2004.

[69] S. Xu, Z. Nie, M. Seo et al., "Generation of monodisperse particles by using microfluidics: control over size, shape, and composition," Angewandte Chemie International Edition, vol. 44, no. 5, pp. 724-728, 2005.

[70] N. A. Peppas and A. R. Khare, "Preparation, structure and diffusional behavior of hydrogels in controlled release," Advanced Drug Delivery Reviews, vol. 11, no. 1-2, pp. 1-35, 1993.

[71] T. Alexakis, K. Boadid, D. Guong et al., "Microencapsulation of DNA within alginate microspheres and crosslinked chitosan membranes for in vivo application," Applied Biochemistry and Biotechnology, vol. 50, no. 1, pp. 93-106, 1995.

[72] C. P. Reis, A. J. Ribeiro, R. J. Neufeld, and F. Veiga, "Alginate microparticles as novel carrier for oral insulin delivery,"
Biotechnology and Bioengineering, vol. 96, no. 5, pp. 977-989, 2007.

[73] G. Steinhoff, U. Stock, N. Karim et al., "Tissue engineering of pulmonary heart valves on allogenic acellular matrix conduits: In vivo restoration of valve tissue," Circulation, vol. 102, no. 19, pp. III50-III55, 2000.

[74] D. E. Zhao, R. B. Li, W. Y. Liu et al., "Tissue-engineered heart valve on acellular aortic valve scaffold: in-vivo study," Asian Cardiovascular and Thoracic Annals, vol. 11, no. 2, pp. 153156, 2003.

[75] H. C. Liang, Y. Chang, C. K. Hsu, M. H. Lee, and H. W. Sung, "Effects of crosslinking degree of an acellular biological tissue on its tissue regeneration pattern," Biomaterials, vol. 25, no. 17, pp. 3541-3552, 2004.

[76] A. Tachibana, Y. Furuta, H. Takeshima, T. Tanabe, and K. Yamauchi, "Fabrication of wool keratin sponge scaffolds for long-term cell cultivation," Journal of Biotechnology, vol. 93, no. 2, pp. 165-170, 2002.

[77] A. Tachibana, S. Kaneko, T. Tanabe, and K. Yamauchi, "Rapid fabrication of keratin-hydroxyapatite hybrid sponges toward osteoblast cultivation and differentiation," Biomaterials, vol. 26, no. 3, pp. 297-302, 2005.

[78] K. Katoh, T. Tanabe, and K. Yamauchi, "Novel approach to fabricate keratin sponge scaffolds with controlled pore size and porosity," Biomaterials, vol. 25, no. 18, pp. 4255-4262, 2004.

[79] J. Doshi and D. H. Reneker, "Electrospinning process and applications of electrospun fibers," Journal of Electrostatics, vol. 35, no. 2-3, pp. 151-160, 1995.

[80] W. J. Li, K. G. Danielson, P. G. Alexander, and R. S. Tuan, "Biological response of chondrocytes cultured in threedimensional nanofibrous poly(E-caprolactone) scaffolds," Journal of Biomedical Materials Research A, vol. 67, no. 4, pp. 1105-1114, 2003.

[81] J. Zeng, A. Aigner, F. Czubayko, T. Kissel, J. H. Wendorff, and A. Greiner, "Poly(vinyl alcohol) nanofibers by electrospinning as a protein delivery system and the retardation of enzyme release by additional polymer coatings," Biomacromolecules, vol. 6, no. 3, pp. 1484-1488, 2005.

[82] S. Hirano, M. Zhang, M. Nakagawa, and T. Miyata, "Wet spun chitosan-collagen fibers, their chemical Nmodifications, and blood compatibility," Biomaterials, vol. 21, no. 10, pp. 997-1003, 2000.

[83] S. J. Pomfret, P. N. Adams, N. P. Comfort, and A. P. Monkman, "Electrical and mechanical properties of polyaniline fibres produced by a one-step wet spinning process," Polymer, vol. 41, no. 6, pp. 2265-2269, 2000.

[84] H. Okuzaki, Y. Harashina, and H. Yan, "Highly conductive PEDOT/PSS microfibers fabricated by wet-spinning and diptreatment in ethylene glycol," European Polymer Journal, vol. 45 , no. 1, pp. 256-261, 2009.

[85] J. Lyons, C. Li, and F. Ko, "Melt-electrospinning-part I: processing parameters and geometric properties," Polymer, vol. 45 , no. 22, pp. 7597-7603, 2004.

[86] C. J. Ellison, A. Phatak, D. W. Giles, C. W. Macosko, and F. S. Bates, "Melt blown nanofibers: fiber diameter distributions and onset of fiber breakup," Polymer, vol. 48, no. 11, pp. 3306-3316, 2007.

[87] K. Kim, C. Lee, I. W. Kim, and J. Kim, "Performance modification of a melt-blown filter medium via an additional nano-web layer prepared by electrospinning," Fibers and Polymers, vol. 10, no. 1, pp. 60-64, 2009.

[88] M. J. B. Wissink, R. Beernink, J. S. Pieper et al., "Binding and release of basic fibroblast growth factor from heparinized 
collagen matrices," Biomaterials, vol. 22, no. 16, pp. 22912299, 2001.

[89] F. Causa, P. A. Netti, and L. Ambrosio, "A multi-functional scaffold for tissue regeneration: the need to engineer a tissue analogue," Biomaterials, vol. 28, no. 34, pp. 5093-5099, 2007.

[90] Y. C. Ho, F. L. Mi, H. W. Sung, and P. L. Kuo, "Heparinfunctionalized chitosan-alginate scaffolds for controlled release of growth factor," International Journal of Pharmaceutics, vol. 376, no. 1-2, pp. 69-75, 2009.

[91] P. Sepulveda and J. G. P. Binner, "Processing of cellular ceramics by foaming and in situ polymerisation of organic monomers," Journal of the European Ceramic Society, vol. 19, no. 12, pp. 2059-2066, 1999.

[92] Q. Z. Chen, I. D. Thompson, and A. R. Boccaccini, “45S5 Bioglass ${ }^{\circledR}$-derived glass-ceramic scaffolds for bone tissue engineering," Biomaterials, vol. 27, no. 11, pp. 2414-2425, 2006.

[93] I. H. Jo, K. H. Shin, Y. M. Soon, Y. H. Koh, J. H. Lee, and H. E. Kim, "Highly porous hydroxyapatite scaffolds with elongated pores using stretched polymeric sponges as novel template," Materials Letters, vol. 63, no. 20, pp. 1702-1704, 2009.

[94] F. Li, Q. L. Feng, F. Z. Cui, H. D. Li, and H. Schubert, "A simple biomimetic method for calcium phosphate coating," Surface and Coatings Technology, vol. 154, no. 1, pp. 88-93, 2002.

[95] J. Chen, B. Chu, and B. S. Hsiao, "Mineralization of hydroxyapatite in electrospun nanofibrous poly(L-lactic acid) scaffolds," Journal of Biomedical Materials Research A, vol. 79, no. 2, pp. 307-317, 2006.

[96] F. Yang, J. G. C. Wolke, and J. A. Jansen, "Biomimetic calcium phosphate coating on electrospun poly( $\varepsilon$-caprolactone) scaffolds for bone tissue engineering," Chemical Engineering Journal, vol. 137, no. 1, pp. 154-161, 2008.

[97] A. V. Lemmo, D. J. Rose, and T. C. Tisone, "Inkjet dispensing technology: applications in drug discovery," Current Opinion in Biotechnology, vol. 9, no. 6, pp. 615-617, 1998.

[98] P. Calvert, "Inkjet printing for materials and devices," Chemistry of Materials, vol. 13, no. 10, pp. 3299-3305, 2001.

[99] L. Pardo, W. Cris Wilson, and T. Boland, "Characterization of patterned self-assembled monolayers and protein arrays generated by the ink-jet method," Langmuir, vol. 19, no. 5, pp. 1462-1466, 2003.

[100] W. Y. Yeong, C. K. Chua, K. F. Leong, M. Chandrasekaran, and M. W. Lee, "Indirect fabrication of collagen scaffold based on inkjet printing technique," Rapid Prototyping Journal, vol. 12, no. 4, pp. 229-237, 2006.

[101] V. Mironov, T. Boland, T. Trusk, G. Forgacs, and R. R. Markwald, "Organ printing: computer-aided jet-based 3D tissue engineering," Trends in Biotechnology, vol. 21, no. 4, pp. 157-161, 2003.

[102] W. Sun, A. Darling, B. Starly, and J. Nam, "Computeraided tissue engineering: overview, scope and challenges," Biotechnology and Applied Biochemistry, vol. 39, part 1, pp. 29-47, 2004.

[103] W. Sun and P. Lal, "Recent development on computer aided tissue engineering-a review," Computer Methods and Programs in Biomedicine, vol. 67, no. 2, pp. 85-103, 2002.

[104] W. Sun, B. Starly, A. Darling, and C. Gomez, "Computeraided tissue engineering: application to biomimetic modelling and design of tissue scaffolds," Biotechnology and Applied Biochemistry, vol. 39, no. 1, pp. 49-58, 2004.

[105] Z. Fang, B. Starly, and W. Sun, "Computer-aided characterization for effective mechanical properties of porous tissue scaffolds," CAD Computer Aided Design, vol. 37, no. 1, pp. 65-72, 2005.

[106] S. Lalan, I. Pomerantseva, and J. P. Vacanti, "Tissue engineering and its potential impact on surgery," World Journal of Surgery, vol. 25, no. 11, pp. 1458-1466, 2001.

[107] T. Boland, V. Mironov, A. Gutowska, E. A. Roth, and R. R. Markwald, "Cell and organ printing 2: fusion of cell aggregates in three-dimensional gels," Anatomical Record A, vol. 272, no. 2, pp. 497-502, 2003.

[108] N. Hirata, K. I. Matsumoto, T. Inishita, Y. Takenaka, Y. Suma, and H. Shintani, "Gamma-ray irradiation, autoclave and ethylene oxide sterilization to thermosetting polyurethane: sterilization to polyurethane," Radiation Physics and Chemistry, vol. 46, no. 3, pp. 377-381, 1995.

[109] K. A. Hooper, J. D. Cox, and J. Kohn, "Comparison of the effect of ethylene oxide and $\gamma$-irradiation on selected tyrosine-derived polycarbonates and poly(L-lactic acid)," Journal of Applied Polymer Science, vol. 63, no. 11, pp. 14991510, 1997.

[110] C. E. Holy, C. Cheng, J. E. Davies, and M. S. Shoichet, "Optimizing the sterilization of PLGA scaffolds for use in tissue engineering," Biomaterials, vol. 22, no. 1, pp. 25-31, 2001.

[111] C. Volland, M. Wolff, and T. Kissel, "The influence of terminal gamma-sterilization on captopril containing poly(D,Llactide-co-glycolide) microspheres," Journal of Controlled Release, vol. 31, no. 3, pp. 293-304, 1994.

[112] M. B. Sintzel, K. S. Abdellaoui, K. Mader et al., "Influence of irradiation sterilization on a semi-solid poly(ortho ester)," International Journal of Pharmaceutics, vol. 175, pp. 165-176, 1998.

[113] L. Montanari, M. Costantini, E. C. Signoretti et al., "Gamma irradiation effects on poly(DL-lactictide-co-glycolide) microspheres," Journal of Controlled Release, vol. 56, no. 1-3, pp. 219-229, 1998.

[114] M. Ohrlander, R. Erickson, R. Palmgren, A. Wirsen, and A. C. Albertsson, "The effect of electron beam irradiation on PCL and PDXO-X monitored by luminescence and electron spin resonance measurements," Polymer, vol. 41, pp. 1277-1286, 1999.

[115] J. S. C. Loo, C. P. Ooi, and F. Y. C. Boey, "Degradation of poly(lactide-co-glycolide) (PLGA) and poly(L-lactide) (PLLA) by electron beam radiation," Biomaterials, vol. 26, no. 12, pp. 1359-1367, 2005.

[116] K. Odelius, P. Plikk, and A. C. Albertsson, "The influence of composition of porous copolyester scaffolds on reactions induced by irradiation sterilization," Biomaterials, vol. 29, no. 2, pp. 129-140, 2008.

[117] E. M. Darmady, K. E. Hughes, J. D. Jones, D. Prince, and W. Tuke, "Sterilization by dry heat," Journal of Clinical Pathology, vol. 14, pp. 38-44, 1961.

[118] Q. Fu, M. N. Rahaman, B. S. Bal, and R. F. Brown, "In vitro cellular response to hydroxyapatite scaffolds with oriented pore architectures," Materials Science and Engineering C, vol. 29, no. 7, pp. 2147-2153, 2009.

[119] F. A. Müller, L. Müller, I. Hofmann, P. Greil, M. M. Wenzel, and R. Staudenmaier, "Cellulose-based scaffold materials for cartilage tissue engineering," Biomaterials, vol. 27, no. 21, pp. 3955-3963, 2006.

[120] K. Gellynck, P. C. M. Verdonk, E. Van Nimmen et al., "Silkworm and spider silk scaffolds for chondrocyte support," Journal of Materials Science: Materials in Medicine, vol. 19, no. 11, pp. 3399-3409, 2008. 
[121] S. Terasaka, Y. Iwasaki, N. Shinya, and T. Uchida, "Fibrin glue and polyglycolic acid nonwoven fabric as a biocompatible dural substitute," Neurosurgery, vol. 58, no. 1, pp. S-134-S138, 2006.

[122] P. B. Maurus and C. C. Kaeding, "Bioabsorbable implant material review," Operative Techniques in Sports Medicine, vol. 12, no. 3, pp. 158-160, 2004.

[123] H. H. Lu, J. A. Cooper, S. Manuel et al., "Anterior cruciate ligament regeneration using braided biodegradable scaffolds: in vitro optimization studies," Biomaterials, vol. 26, no. 23, pp. 4805-4816, 2005.

[124] J. A. Cooper, H. H. Lu, F. K. Ko, J. W. Freeman, and C. T. Laurencin, "Fiber-based tissue-engineered scaffold for ligament replacement: design considerations and in vitro evaluation," Biomaterials, vol. 26, no. 13, pp. 1523-1532, 2005.

[125] M. Zilberman, K. D. Nelson, and R. C. Eberhart, "Mechanical properties and in vitro degradation of bioresorbable fibers and expandable fiber-based stents," Journal of Biomedical Materials Research B, vol. 74, no. 2, pp. 792-799, 2005.

[126] S. Leinonen, E. Suokas, M. Veiranto, P. Tormala, T. Waris, and N. Ashammakhi, "Healing power of bioadsorbable ciprofloxacin- containing self reinforced poly(L/DL-lactide 70/30 bioactive glass 13 miniscrews in human cadaver bone," Journal of Craniofacial Surgery, vol. 13, pp. 212-218, 2002.

[127] C. W. Pouton and S. Akhtar, "Biosynthetic polyhydroxyalkanoates and their potential in drug delivery," Advanced Drug Delivery Reviews, vol. 18, no. 2, pp. 133-162, 1996.

[128] B. Saad, T. D. Hirt, M. Welti, G. K. Uhlschmid, P. Neuenschwander, and U. W. Suter, "Development of degradable polyesterurethanes for medical applications: in vitro and in vivo evaluations," Journal of Biomedical Materials Research, vol. 36, no. 1, pp. 65-74, 1997.

[129] I. C. Bonzani, R. Adhikari, S. Houshyar, R. Mayadunne, P. Gunatillake, and M. M. Stevens, "Synthesis of twocomponent injectable polyurethanes for bone tissue engineering," Biomaterials, vol. 28, no. 3, pp. 423-433, 2007.

[130] J. Heller, "Ocular delivery using poly(ortho esters)," Advanced Drug Delivery Reviews, vol. 57, no. 14, pp. 20532062, 2005.

[131] D. S. Katti, S. Lakshmi, R. Langer, and C. T. Laurencin, "Toxicity, biodegradation and elimination of polyanhydrides," Advanced Drug Delivery Reviews, vol. 54, no. 7, pp. 933-961, 2002.

[132] C. Vauthier, C. Dubernet, C. Chauvierre, I. Brigger, and P. Couvreur, "Drug delivery to resistant tumors: the potential of poly(alkyl cyanoacrylate) nanoparticles," Journal of Controlled Release, vol. 93, no. 2, pp. 151-160, 2003.

[133] P. Sai and M. Babu, "Collagen based dressings—a review," Burns, vol. 26, no. 1, pp. 54-62, 2000.

[134] X. Duan, C. McLaughlin, M. Griffith, and H. Sheardown, "Biofunctionalization of collagen for improved biological response: scaffolds for corneal tissue engineering," Biomaterials, vol. 28, no. 1, pp. 78-88, 2007.

[135] D. R. Hunt, S. A. Joanovic, U. M. E. Wikesjo, J. M. Wozney, and D. W. Bernard, "Hyaluronan supports recombinant human bone morphogenetic protein-2 induced bone reconstruction of advanced alveolar ridge defects in dogs. A pilot study," Journal of Periodontology, vol. 72, pp. 651-657, 2001.

[136] B. L. Eppley and B. Dadvand, "Injectable soft-tissue fillers: clinical overview," Plastic and Reconstructive Surgery, vol. 118, no. 4, pp. 98e-106e, 2006.

[137] Y. Kato, S. Nakamura, and M. Nishimura, "Beneficial actions of hyaluronan (HA) on arthritic joints: effects of molecular weight of HA on elasticity of cartilage matrix," Biorheology, vol. 43, no. 3-4, pp. 347-354, 2006.

[138] D. W. Hutmacher, "Scaffold design and fabrication technologies for engineering tissues-State of the art and future perspectives," Journal of Biomaterials Science, vol. 12, no. 1, pp. 107-124, 2001.

[139] L. E. Freed, G. Vunjak-Novakovic, R. J. Biron et al., "Biodegradable polymer scaffolds for tissue engineering," Biotechnology, vol. 12, no. 7, pp. 689-693, 1994.

[140] L. E. Freed and G. Vunjak-Novakovic, "Culture of organized cell communities," Advanced Drug Delivery Reviews, vol. 33, no. 1-2, pp. 15-30, 1998.

[141] P. X. Ma and R. Zhang, "Microtubular architecture of biodegradable polymer scaffolds," Journal of Biomedical Materials Research, vol. 56, no. 4, pp. 469-477, 2001.

[142] S. Freiberg and X. X. Zhu, "Polymer microspheres for controlled drug release," International Journal of Pharmaceutics, vol. 282, no. 1-2, pp. 1-18, 2004.

[143] D. J. Mooney, G. Organ, J. P. Vacanti, and R. Langer, "Design and fabrication of biodegradable polymer devices to engineer tubular tissues," Cell Transplantation, vol. 3, no. 2, pp. 203210, 1994.

[144] G. Wei and P. X. Ma, "Structure and properties of nanohydroxyapatite/polymer composite scaffolds for bone tissue engineering," Biomaterials, vol. 25, no. 19, pp. 4749-4757, 2004.

[145] E. M. Ouriemchi and J. M. Vergnaud, "Processes of drug transfer with three different polymeric systems with transdermal drug delivery," Computational and Theoretical Polymer Science, vol. 10, no. 5, pp. 391-401, 2000.

[146] Q. Hou, D. W. Grijpma, and J. Feijen, "Preparation of porous poly( $\varepsilon$-caprolactone) structures," Macromolecular Rapid Communications, vol. 23, no. 4, pp. 247-252, 2002.

[147] Q. Hou, D. W. Grijpma, and J. Feijen, "Porous polymeric structures for tissue engineering prepared by a coagulation, compression moulding and salt leaching technique," Biomaterials, vol. 24, no. 11, pp. 1937-1947, 2003.

[148] M. Cabodi, N. W. Choi, J. P. Gleghorn, C. S. D. Lee, L. J. Bonassar, and A. D. Stroock, "A microfluidic biomaterial," Journal of the American Chemical Society, vol. 127, no. 40, pp. 13788-13789, 2005.

[149] M. S. Jhon and J. D. Andrade, "Water and hydrogels," Journal of Biomedical Materials Research, vol. 7, no. 6, pp. 509-522, 1973.

[150] A. S. Hoffman, "Hydrogels for biomedical applications," Annals of the New York Academy of Sciences, vol. 944, pp. 6273, 2001.

[151] J. A. Hubbell, "Bioactive biomaterials," Current Opinion in Biotechnology, vol. 10, no. 2, pp. 123-129, 1999.

[152] K. Y. Lee and D. J. Mooney, "Hydrogels for tissue engineering," Chemical Reviews, vol. 101, no. 7, pp. 1869-1879, 2001.

[153] N. A. Peppas and A. R. Khare, "Preparation, structure and diffusional behavior of hydrogels in controlled release," Advanced Drug Delivery Reviews, vol. 11, no. 1-2, pp. 1-35, 1993.

[154] Y. Tabata, "Tissue regeneration based on growth factor release," Tissue Engineering, vol. 9, no. 4, pp. 5-15, 2003.

[155] S. J. Bryant and K. S. Anseth, "The effects of scaffold thickness on tissue engineered cartilage in photocrosslinked poly(ethylene oxide) hydrogels," Biomaterials, vol. 22, no. 6, pp. 619-626, 2001.

[156] D. G. Wallace and J. Rosenblatt, "Collagen gel systems for sustained delivery and tissue engineering," Advanced Drug Delivery Reviews, vol. 55, no. 12, pp. 1631-1649, 2003. 
[157] U. J. Kim, J. Park, C. Li, H. J. Jin, R. Valluzzi, and D. L. Kaplan, "Structure and properties of silk hydrogels," Biomacromolecules, vol. 5, no. 3, pp. 786-792, 2004.

[158] D. Eyrich, F. Brandl, B. Appel et al., "Long-term stable fibrin gels for cartilage engineering," Biomaterials, vol. 28, no. 1, pp. 55-65, 2007.

[159] L. A. Solchaga, J. Gao, J. E. Dennis et al., "Treatment of osteochondral defects with autologous bone marrow in a hyaluronan-based delivery vehicle," Tissue Engineering, vol. 8, no. 2, pp. 333-347, 2002.

[160] H. J. Kong, M. K. Smith, and D. J. Mooney, "Designing alginate hydrogels to maintain viability of immobilized cells," Biomaterials, vol. 24, no. 22, pp. 4023-4029, 2003.

[161] J. K. Francis Suh and H. W. T. Matthew, "Application of chitosan-based polysaccharide biomaterials in cartilage tissue engineering: a review," Biomaterials, vol. 21, no. 24, pp. 25892598, 2000.

[162] R. H. Schmedlen, K. S. Masters, and J. L. West, "Photocrosslinkable polyvinyl alcohol hydrogels that can be modified with cell adhesion peptides for use in tissue engineering," Biomaterials, vol. 23, no. 22, pp. 4325-4332, 2002.

[163] E. Behravesh and A. G. Mikos, "Three-dimensional culture of differentiating marrow stromal osteoblasts in biomimetic poly(propylene fumarate-co-ethylene glycol)-based macroporous hydrogels," Journal of Biomedical Materials Research A, vol. 66, no. 3, pp. 698-706, 2003.

[164] S. J. Bryant, K. A. Davis-Arehart, N. Luo, R. K. Shoemaker, J. A. Arthur, and K. S. Anseth, "Synthesis and characterization of photopolymerized multifunctional hydrogels: water-soluble poly(vinyl alcohol) and chondroitin sulfate macromers for chondrocyte encapsulation," Macromolecules, vol. 37, no. 18, pp. 6726-6733, 2004.

[165] P. Berndt, G. B. Fields, and M. Tirrell, "Synthetic lipidation of peptides and amino acids: monolayer structure and properties," Journal of the American Chemical Society, vol. 117, no. 37, pp. 9515-9522, 1995.

[166] S. R. Bhattarai, N. Bhattarai, H. K. Yi, P. H. Hwang, D. I. Cha, and H. Y. Kim, "Novel biodegradable electrospun membrane: scaffold for tissue engineering," Biomaterials, vol. 25, no. 13, pp. 2595-2602, 2004.

[167] Z. Ma, M. Kotaki, R. Inai, and S. Ramakrishna, "Potential of nanofiber matrix as tissue-engineering scaffolds," Tissue Engineering, vol. 11, no. 1-2, pp. 101-109, 2005.

[168] R. Vasita and D. S. Katti, "Nanofibers and their applications in tissue engineering," International Journal of Nanomedicine, vol. 1, no. 1, pp. 15-30, 2006.

[169] J. A. Matthews, G. E. Wnek, D. G. Simpson, and G. L. Bowlin, "Electrospinning of collagen nanofibers," Biomacromolecules, vol. 3, no. 2, pp. 232-238, 2002.

[170] Y. Zhang, H. Ouyang, T. L. Chwee, S. Ramakrishna, and Z. M. Huang, "Electrospinning of gelatin fibers and gelatin/PCL composite fibrous scaffolds," Journal of Biomedical Materials Research B, vol. 72, no. 1, pp. 156-165, 2005.

[171] X. Geng, O. H. Kwon, and J. Jang, "Electrospinning of chitosan dissolved in concentrated acetic acid solution," Biomaterials, vol. 26, no. 27, pp. 5427-5432, 2005.

[172] I. C. Um, D. Fang, B. S. Hsiao, A. Okamoto, and B. Chu, "Electro-spinning and electro-blowing of hyaluronic acid," Biomacromolecules, vol. 5, no. 4, pp. 1428-1436, 2004.

[173] H. J. Jin, J. Chen, V. Karageorgiou, G. H. Altman, and D. L. Kaplan, "Human bone marrow stromal cell responses on electrospun silk fibroin mats," Biomaterials, vol. 25, no. 6, pp. 1039-1047, 2004.
[174] F. Yang, R. Murugan, S. Wang, and S. Ramakrishna, "Electrospinning of nano/micro scale poly(l-lactic acid) aligned fibers and their potential in neural tissue engineering," Biomaterials, vol. 26, no. 15, pp. 2603-2610, 2005.

[175] S. A. Riboldi, M. Sampaolesi, P. Neuenschwander, G. Cossu, and S. Mantero, "Electrospun degradable polyesterurethane membranes: potential scaffolds for skeletal muscle tissue engineering," Biomaterials, vol. 26, no. 22, pp. 4606-4615, 2005.

[176] W. J. Li, K. G. Danielson, P. G. Alexander, and R. S. Tuan, "Biological response of chondrocytes cultured in threedimensional nanofibrous poly(e-caprolactone) scaffolds," Journal of Biomedical Materials Research A, vol. 67, no. 4, pp. 1105-1114, 2003.

[177] K. Uematsu, K. Hattori, Y. Ishimoto et al., "Cartilage regeneration using mesenchymal stem cells and a three-dimensional poly-lactic-glycolic acid (PLGA) scaffold," Biomaterials, vol. 26, no. 20, pp. 4273-4279, 2005.

[178] E. R. Kenawy, G. L. Bowlin, K. Mansfield et al., "Release of tetracycline hydrochloride from electrospun poly(ethyleneco-vinylacetate), poly(lactic acid), and a blend," Journal of Controlled Release, vol. 81, no. 1-2, pp. 57-64, 2002.

[179] X. M. Mo, C. Y. Xu, M. Kotaki, and S. Ramakrishna, "Electrospun P(LLA-CL) nanofiber: a biomimetic extracellular matrix for smooth muscle cell and endothelial cell proliferation," Biomaterials, vol. 25, no. 10, pp. 1883-1890, 2004.

[180] G. Verreck, I. Chun, J. Rosenblatt et al., "Incorporation of drugs in an amorphous state into electrospun nanofibers composed of a water-insoluble, nonbiodegradable polymer," Journal of Controlled Release, vol. 92, no. 3, pp. 349-360, 2003.

[181] M. Singh, C. P. Morris, R. J. Ellis, M. S. Detamore, and C. Berkland, "Microsphere-based seamless scaffolds containing macroscopic gradients of encapsulated factors for tissue engineering," Tissue Engineering C, vol. 14, no. 4, pp. 299_ 309, 2008.

[182] M. Singh, B. Sandhu, A. Scurto, C. Berkland, and M. S. Detamore, "Microsphere-based scaffolds for cartilage tissue engineering: using subcritical $\mathrm{CO}_{2}$ as a sintering agent," Acta Biomaterialia, vol. 6, no. 1, pp. 137-143, 2010.

[183] D. Stephens, L. Li, D. Robinson et al., "Investigation of the in vitro release of gentamicin from a polyanhydride matrix," Journal of Controlled Release, vol. 63, no. 3, pp. 305-317, 2000.

[184] C. Berkland, M. King, A. Cox, K. Kim, and D. W. Pack, "Precise control of PLG microsphere size provides enhanced control of drug release rate," Journal of Controlled Release, vol. 82, no. 1, pp. 137-147, 2002.

[185] H. B. Ravivarapu, K. Burton, and P. P. DeLuca, "Polymer and microsphere blending to alter the release of a peptide from PLGA microspheres," European Journal of Pharmaceutics and Biopharmaceutics, vol. 50, no. 2, pp. 263-270, 2000.

[186] R. A. Jain, C. T. Rhodes, A. M. Railkar, A. W. Malick, and N. H. Shah, "Controlled delivery of drugs from a novel injectable in situ formed biodegradable PLGA microsphere system," Journal of Microencapsulation, vol. 17, no. 3, pp. 343-362, 2000.

[187] C. Berkland, K. Kim, and D. W. Pack, "PLG microsphere size controls drug release rate through several competing factors," Pharmaceutical Research, vol. 20, no. 7, pp. 1055-1062, 2003.

[188] M. Borden, M. Attawia, Y. Khan, S. F. El-Amin, and C. T. Laurencin, "Tissue-engineered bone formation in vivo using a novel sintered polymeric microsphere matrix," Journal of Bone and Joint Surgery B, vol. 86, no. 8, pp. 1200-1208, 2004. 
[189] J. Yao, S. Radin, P. S. Leboy P., and P. Ducheyne, "The effect of bioactive glass content on synthesis and bioactivity of composite poly (lactic-co-glycolic acid)/bioactive glass substrate for tissue engineering," Biomaterials, vol. 26, no. 14, pp. 1935-1943, 2005.

[190] A. Jaklenec, E. Wan, M. E. Murray, and E. Mathiowitz, "Novel scaffolds fabricated from protein-loaded microspheres for tissue engineering," Biomaterials, vol. 29, no. 2, pp. 185-192, 2008.

[191] A. Jaklenec, A. Hinckfuss, B. Bilgen, D. M. Ciombor, R. Aaron, and E. Mathiowitz, "Sequential release of bioactive IGF-I and TGF- $\beta 1$ from PLGA microsphere-based scaffolds," Biomaterials, vol. 29, no. 10, pp. 1518-1525, 2008.

[192] J. L. Brown, L. S. Nair, and C. T. Laurencin, "Solvent/nonsolvent sintering: a novel route to create porous microsphere scaffolds for tissue regeneration," Journal of Biomedical Materials Research B, vol. 86, no. 2, pp. 396-406, 2008.

[193] S. P. Nukavarapu, S. G. Kumbar, J. L. Brown et al., "Polyphosphazene/nano-hydroxyapatite composite microsphere scaffolds for bone tissue engineering," Biomacromolecules, vol. 9, no. 7, pp. 1818-1825, 2008.

[194] M. Borden, M. Attawia, and C. T. Laurencin, "The sintered microsphere matrix for bone tissue engineering: in vitro osteoconductivity studies," Journal of Biomedical Materials Research, vol. 61, no. 3, pp. 421-429, 2002.

[195] Y. M. Khan, D. S. Katti, and C. T. Laurencin, "Novel polymersynthesized ceramic composite-based system for bone repair: an in vitro evaluation," Journal of Biomedical Materials Research A, vol. 69, no. 4, pp. 728-737, 2004.

[196] K. Rezwan, Q. Z. Chen, J. J. Blaker, and A. R. Boccaccini, "Biodegradable and bioactive porous polymer/inorganic composite scaffolds for bone tissue engineering," Biomaterials, vol. 27, no. 18, pp. 3413-3431, 2006.

[197] L. L. Hench, "Bioceramics: from concept to clinic," American Ceramic Society Bulletin, vol. 72, pp. 93-98, 1993.

[198] R. L. Hentrich Jr., G. A. Graves Jr., H. G. Stein, and P. K. Bajpai, "Evaluation of inert and resorbable ceramics for future clinical orthopedic applications," Journal of Biomedical Materials Research, vol. 5, no. 1, pp. 25-51, 1971.

[199] J. B. Park and R. S. Lakes, Biomaterials -An Introduction, Plenum Press, New York, NY, USA, 2nd edition, 1992.

[200] J. J. Blaker, J. E. Gough, V. Maquet, I. Notingher, and A. R. Boccaccini, "In vitro evaluation of novel bioactive composites based on Bioglass ${ }^{\circledR}$-filled polylactide foams for bone tissue engineering scaffolds," Journal of Biomedical Materials Research A, vol. 67, no. 4, pp. 1401-1411, 2003.

[201] H. W. Kim, E. J. Lee, I. K. Jun, H. E. Kim, and J. C. Knowles, "Degradation and drug release of phosphate glass/polycaprolactone biological composites for hard-tissue regeneration," Journal of Biomedical Materials Research B, vol. 75, no. 1, pp. 34-41, 2005.

[202] C. Du, F. Z. Cui, X. D. Zhu, and K. De Groot, "Three-dimensional nano-HAp/collagen matrix loading with osteogenic cells in organ culture," Journal of Biomedical Materials Research, vol. 44, no. 4, pp. 407-415, 1999.

[203] A. Bigi, E. Boanini, S. Panzavolta, N. Roveri, and K. Rubini, "Bonelike apatite growth on hydroxyapatite-gelatin sponges from simulated body fluid," Journal of Biomedical Materials Research, vol. 59, no. 4, pp. 709-715, 2002.

[204] Y. Zhang and M. Zhang, "Synthesis and characterization of macroporous chitosan/calcium phosphate composite scaffolds for tissue engineering," Journal of Biomedical Materials Research, vol. 55, no. 3, pp. 304-312, 2001.
[205] S. E. Dahms, H. J. Piechota, R. Dahiya, T. F. Lue, and E. A. Tanagho, "Composition and biomechanical properties of the bladder acellular matrix graft: comparative analysis in rat, pig and human," British Journal of Urology, vol. 82, no. 3, pp. 411-419, 1998.

[206] J. J. Yoo, J. Meng, F. Oberpenning, and A. Atala, "Bladder augmentation using allogenic bladder submucosa seeded with cells," Urology, vol. 51, no. 2, pp. 221-225, 1998.

[207] F. Chen, J. J. Yoo, and A. Atala, "Acellular collagen matrix as a possible 'off the shelf' biomaterial for urethral repair," Urology, vol. 54, no. 3, pp. 407-410, 1999.

[208] G. J. Wilson, D. W. Courtman, P. Klement, J. M. Lee, and H. Yeger, "Acellular matrix: a biomaterials approach for coronary artery bypass and heart valve replacement," Annals of Thoracic Surgery, vol. 60, supplement 2, pp. S353-S358, 1995.

[209] S. E. Dahms, H. J. Piechota, L. Nunes, R. Dahiya, T. F. Lue, and E. A. Tanagho, "Free ureteral replacement in rats: regeneration of ureteral wall components in the acellular matrix graft," Urology, vol. 50, no. 5, pp. 818-825, 1997.

[210] M. Probst, R. Dahiya, S. Carrier, and E. A. Tanagho, "Reproduction of functional smooth muscle tissue and partial bladder replacement," British Journal of Urology, vol. 79, no. 4, pp. 505-515, 1997.

[211] T. W. Gilbert, T. L. Sellaro, and S. F. Badylak, "Decellularization of tissues and organs," Biomaterials, vol. 27, no. 19, pp. 3675-3683, 2006.

[212] C. Stamm, A. Khosravi, N. Grabow et al., "Biomatrix/polymer composite material for heart valve tissue engineering," Annals of Thoracic Surgery, vol. 78, no. 6, pp. 20842093, 2004

[213] M. Sokolsky-Papkov, K. Agashi, A. Olaye, K. Shakesheff, and A. J. Domb, "Polymer carriers for drug delivery in tissue engineering," Advanced Drug Delivery Reviews, vol. 59, no. 4-5, pp. 187-206, 2007.

[214] B. D. Boyan, T. W. Hummert, D. D. Dean, and Z. Schwartz, "Role of material surfaces in regulating bone and cartilage cell response," Biomaterials, vol. 17, no. 2, pp. 137-146, 1996.

[215] K. T. Tran, L. Griffith, and A. Wells, "Extracellular matrix signaling through growth factor receptors during wound healing," Wound Repair and Regeneration, vol. 12, no. 3, pp. 262-268, 2004.

[216] K. S. Midwood, L. V. Williams, and J. E. Schwarzbauer, "Tissue repair and the dynamics of the extracellular matrix," International Journal of Biochemistry and Cell Biology, vol. 36, no. 6, pp. 1031-1037, 2004.

[217] R. N. S. Sodhi, "Application of surface analytical and modification techniques to biomaterial research," Journal of Electron Spectroscopy and Related Phenomena, vol. 81, no. 3, pp. 269-284, 1996.

[218] D. M. Brewis and D. Briggs, "Adhesion to polyethylene and polypropylene," Polymer, vol. 22, no. 1, pp. 7-16, 1981.

[219] D. L. Elbert and J. A. Hubbell, "Surface treatments of polymers for biocompatibility," Annual Review of Materials Science, vol. 26, no. 1, pp. 365-394, 1996.

[220] C. A. Léon y León, "New perspectives in mercury porosimetry," Advances in Colloid and Interface Science, vol. 76-77, pp. 341-372, 1998.

[221] A. G. A. Coombes, S. C. Rizzi, M. Williamson, J. E. Barralet, S. Downes, and W. A. Wallace, "Precipitation casting of polycaprolactone for applications in tissue engineering and drug delivery," Biomaterials, vol. 25, no. 2, pp. 315-325, 2004. 
[222] J. H. Brauker, V. E. Carr-Brendel, L. A. Martinson, J. Crudele, W. D. Johnston, and R. C. Johnson, "Neovascularization of synthetic membranes directed by membrane micro architecture," Journal of Biomedical Materials Research, vol. 29, pp. 1517-1524, 1995.

[223] J. J. Klawitter and S. F. Hulbert, "Application of porous ceramics for the attachment of load-bearing internal orthopedic applications," Journal of Biomedical Materials Research A Symposium, vol. 2, pp. 161-168, 1971.

[224] S. Yang, K. F. Leong, Z. Du, and C. K. Chua, "The design of scaffolds for use in tissue engineering - part I: traditional factors," Tissue Engineering, vol. 7, no. 6, pp. 679-689, 2001.

[225] K. Whang, K. E. Healy, D. R. Elenz et al., "Engineering bone regeneration with bioabsorbable scaffolds with novel microarchitecture," Tissue Engineering, vol. 5, no. 1, pp. 3551, 1999.

[226] I. V. Yannas, E. Lee, D. P. Orgill, E. M. Skrabut, and G. F. Murphy, "Synthesis and characterization of a model extracellular matrix that induces partial regeneration of adult mammalian skin," Proceedings of the National Academy of Sciences of the United States of America, vol. 86, no. 3, pp. 933937, 1989.

[227] A. J. Salgado, O. P. Coutinho, and R. L. Reis, "Bone tissue engineering: state of the art and future trends," Macromolecular Bioscience, vol. 4, no. 8, pp. 743-765, 2004.

[228] D. F. Williams, "On the mechanisms of biocompatibility," Biomaterials, vol. 29, no. 20, pp. 2941-2953, 2008.

[229] G. Khang, J. H. Jeon, J. W. Lee, S. C. Cho, and H. B. Lee, “Cell and platelet adhesions on plasma glow discharge-treated poly(lactide-co-glycolide)," Bio-Medical Materials and Engineering, vol. 7, no. 6, pp. 357-368, 1997.

[230] K. D. Colter, M. Shen, and A. T. Bell, "Reduction of progesterone release rate through silicone membranes by plasma polymerization," Biomaterials Medical Devices and Artificial Organs, vol. 5, no. 1, pp. 13-24, 1977.

[231] M. Sato, M. Ishihara, M. Ishihara et al., "Effects of growth factors on heparin-carrying polystyrene-coated atelocollagen scaffold for articular cartilage tissue engineering," Journal of Biomedical Materials Research B, vol. 83, no. 1, pp. 181-188, 2007.

[232] H. Park, K. Y. Lee, S. J. Lee, K. E. Park, and W. H. Park, "Plasma-treated poly(lactic-co-glycolic acid) nanofibers for tissue engineering," Macromolecular Research, vol. 15, no. 3, pp. 238-243, 2007.

[233] S. A. Mitchell, M. R. Davidson, and R. H. Bradley, "Improved cellular adhesion to acetone plasma modified polystyrene surfaces," Journal of Colloid and Interface Science, vol. 281, no. 1, pp. 122-129, 2005.

[234] J. C. Middleton and A. J. Tipton, "Synthetic biodegradable polymers as orthopedic devices," Biomaterials, vol. 21, no. 23, pp. 2335-2346, 2000.

[235] M. A. Woodruff and D. W. Hutmacher, "The return of a forgotten polymer-polycaprolactone in the 21st century," Progress in Polymer Science, vol. 35, no. 10, pp. 1217-1256, 2010.

[236] W. P. Ye, F. S. Du, W. H. Jin, J. Y. Yang, and Y. Xu, "In vitro degradation of poly(caprolactone), poly(lactide) and their block copolymers: influence of composition, temperature and morphology," Reactive and Functional Polymers, vol. 32, no. 2, pp. 161-168, 1997.

[237] K. S. Anseth, C. N. Bowman, and L. Brannon-Peppas, "Mechanical properties of hydrogels and their experimental determination," Biomaterials, vol. 17, no. 17, pp. 1647-1657, 1996.
[238] P. V. Moghe, F. Berthiaume, R. M. Ezzell, M. Toner, R. G. Tompkins, and M. L. Yarmush, "Culture matrix configuration and composition in the maintenance of hepatocyte polarity and function," Biomaterials, vol. 17, no. 3, pp. 373385, 1996.

[239] P. L. Ryan, R. A. Foty, J. Kohn, and M. S. Steinberg, “Tissue spreading on implantable substrates is a competitive outcome of cell-cell vs. cell-substratum adhesivity," Proceedings of the National Academy of Sciences of the United States of America, vol. 98, no. 8, pp. 4323-4327, 2001.

[240] D. E. Ingber, "Mechanical signaling and the cellular response to extracellular matrix in angiogenesis and cardiovascular physiology," Circulation Research, vol. 91, no. 10, pp. 877887, 2002. 

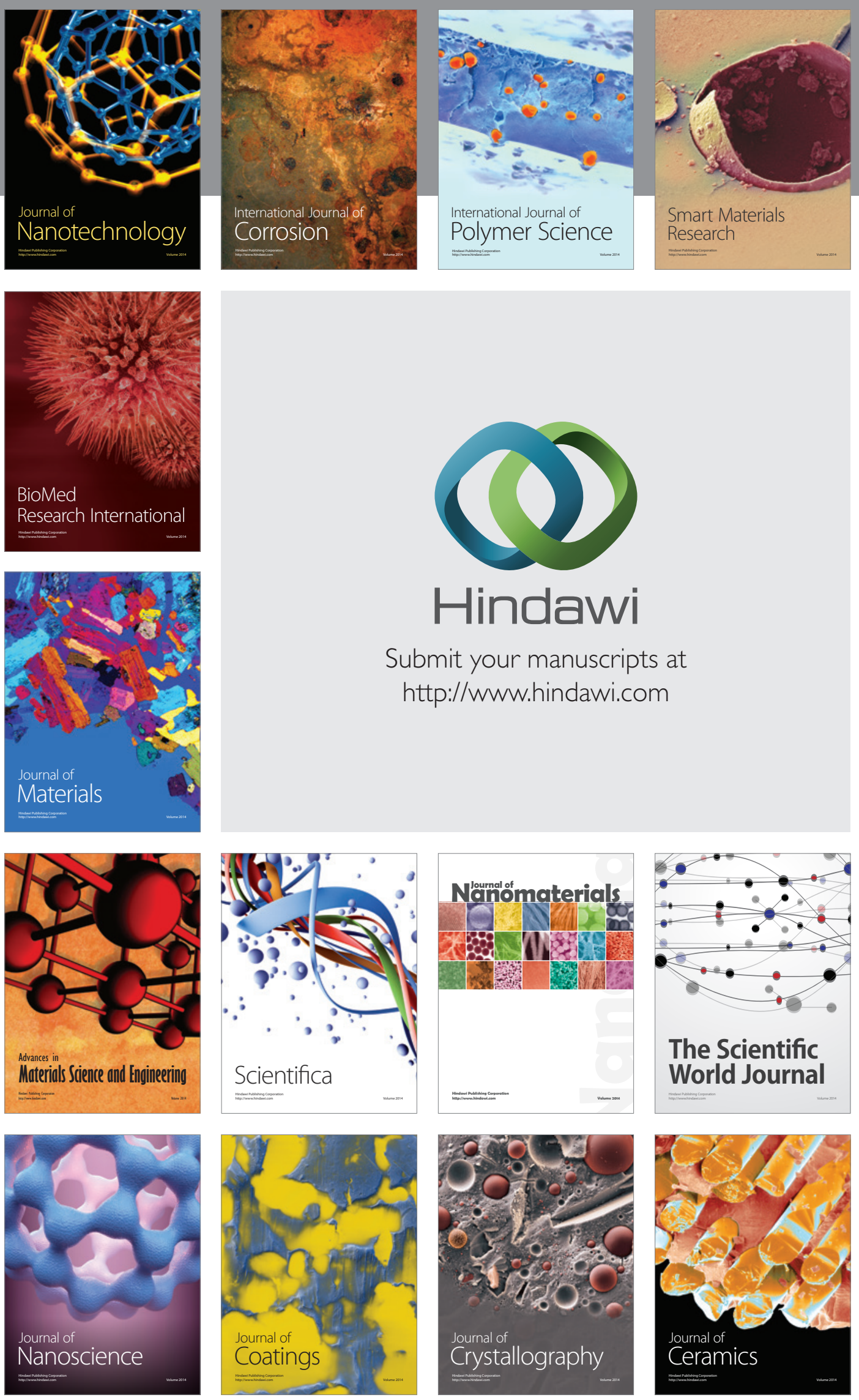

The Scientific World Journal

Submit your manuscripts at

http://www.hindawi.com

\section{World Journal}

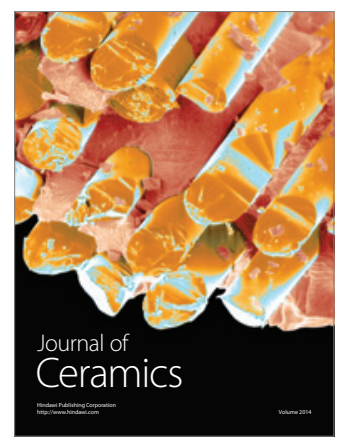

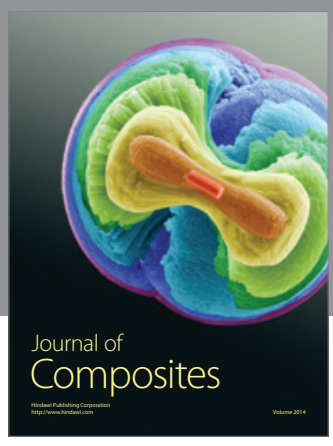
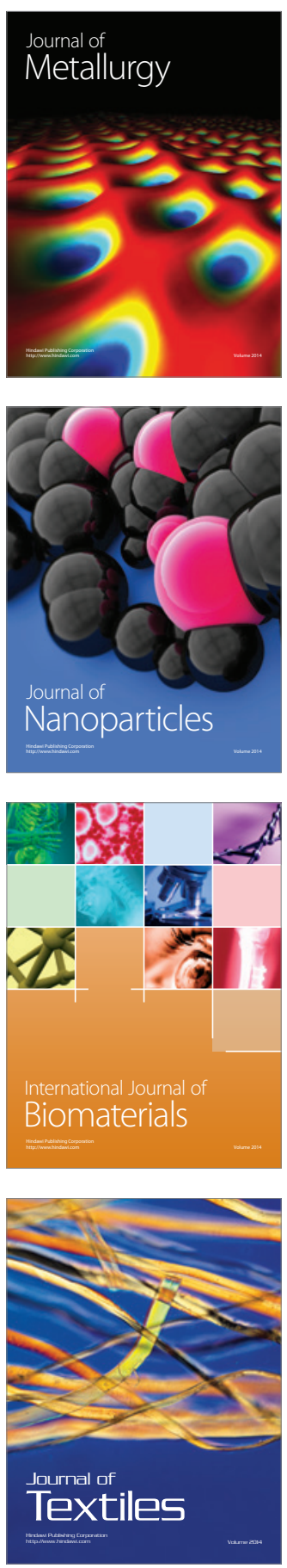